DIW BERLIN

Discussion

Papers
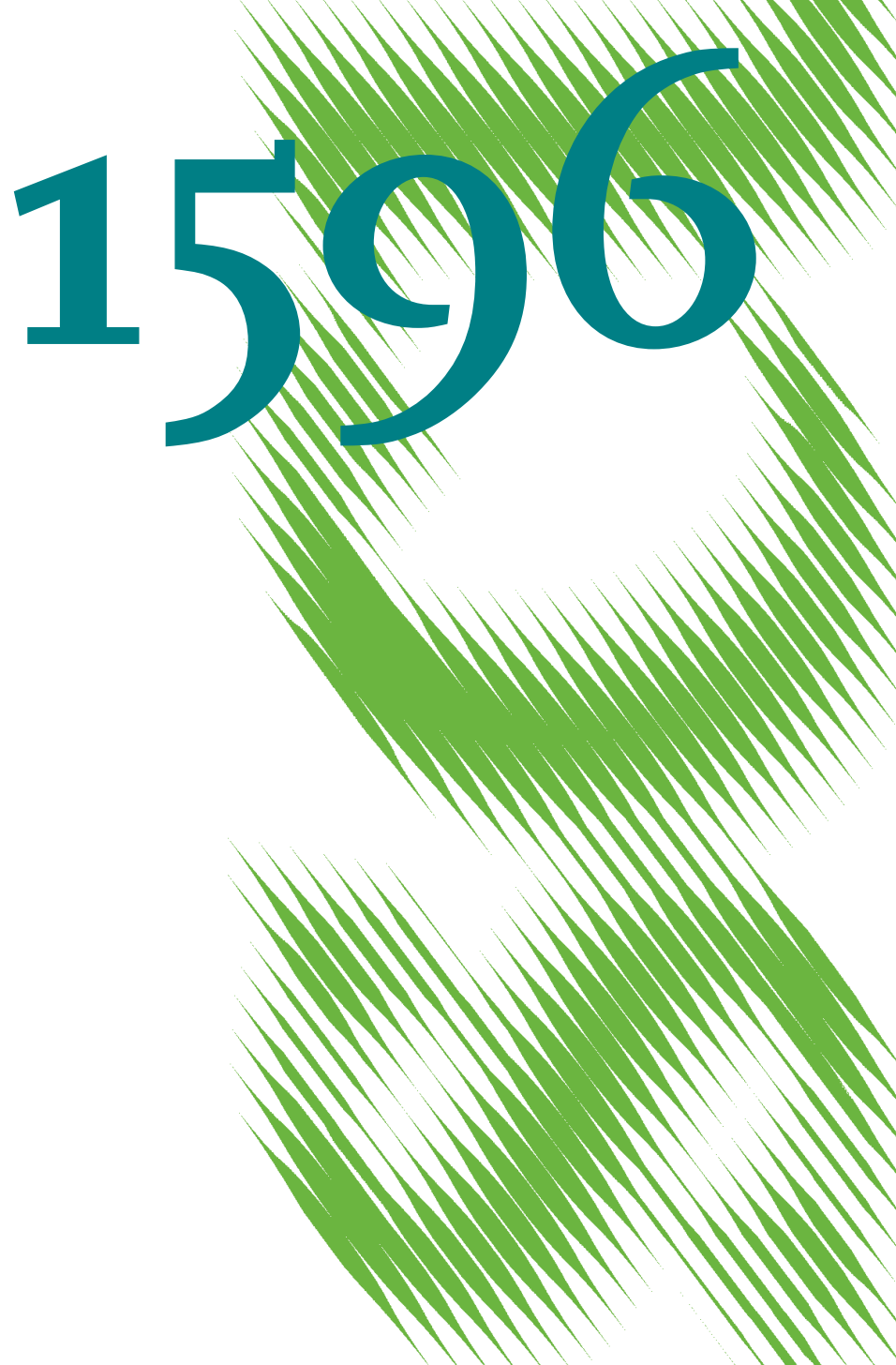

Unconventional Monetary Policy, Fiscal Side Effects and Euro Area (Im)balances 
Opinions expressed in this paper are those of the author(s) and do not necessarily reflect views of the institute.

IMPRESSUM

(C) DIW Berlin, 2016

DIW Berlin

German Institute for Economic Research

Mohrenstr. 58

10117 Berlin

Tel. +49 (30) $89789-0$

Fax +49 (30) $89789-200$

http://www.diw.de

ISSN electronic edition 1619-4535

Papers can be downloaded free of charge from the DIW Berlin website:

http://www.diw.de/discussionpapers

Discussion Papers of DIW Berlin are indexed in RePEc and SSRN:

http://ideas.repec.org/s/diw/diwwpp.html

http://www.ssrn.com/link/DIW-Berlin-German-Inst-Econ-Res.html 


\title{
Unconventional Monetary Policy, Fiscal Side Effects and Euro Area (Im)balances*
}

\author{
Michael Hachula ${ }^{a, b} \quad$ Michele Piffer ${ }^{b} \quad$ Malte Rieth ${ }^{b, \S}$
}

July 21, 2016

\begin{abstract}
We study the macroeconomic effects of unconventional monetary policy in the euro area using structural vector autoregressions, identified with an external instrument. The instrument is the common unexpected variation in euro area sovereign spreads for different maturities on policy announcement days. We first show that expansionary monetary surprises are effective at lowering public and private interest rates and increasing economic activity, consumer prices, and inflation expectations. We also find, however, that the shocks lead to a rise in primary public expenditures, a divergence of consumer prices within the union, and a widening of internal trade balances.
\end{abstract}

JEL classification: E52, E58, E63

Keywords: Central banks, structural VAR with external instruments, fiscal policy, monetary union.

${ }^{*}$ We are thankful to Christiane Baumeister, Refet Gürkaynak, Philipp König, Michele Lenza, Dieter Nautz, Morten Ravn and participants of the RCEA Macro-Money-Finance Workshop in Rimini 2016, the IAAE annual conference in Milan 2016, and an internal seminar for comments and suggestions. We thank Korbinian Breitrainer for research assistance.

${ }^{a}$ Free University Berlin, Department of Economics.

${ }^{b}$ German Institute for Economic Research (DIW Berlin).

$\S$ Corresponding author e-mail: mrieth@diw.de. 


\section{Introduction}

Following the outbreak of the global financial crisis in 2007, nearly all major central banks engaged in unconventional monetary policy, in the form of credit easing, forward guidance, or asset purchases. The new tools spurred an intense public and academic debate about their benefits and costs. While more and more rounds of easing have been implemented, the evidence of the effectiveness of these policies and on how they pass-through to the real economy is still scarce. Even less is known about potential side effects. In this paper, we provide new evidence on the macroeconomic effects of unconventional monetary policy in the euro area.

The public discussion about the benefits and costs of unconventional monetary policy is particularly intense in the euro area. On the one hand, proponents claim that the adopted measures are effective in fulfilling the central bank's mandate of price stability (see Draghi, 2015, 2016, Constancio, 2016). On the other hand, opponents argue that the monetary interventions induce laxer fiscal policy and a widening of euro area imbalances (see Schmidt et al., 2015, Liikanen, 2015, Weidmann and Knot, 2015). They fear that windfall gains from unexpectedly lower interest payments are used to increase primary public expenditures. Moreover, crisis-hit countries could lose competitiveness if prices respond to the common monetary stimulus more strongly there than in other member countries. The public debate develops in parallel to the re-emergence of classic academic questions regarding the effectiveness and fiscal consequences of monetary policy in a currency union (see Orphanides, 2016). How does fiscal react to monetary policy? Are there differences in the responses of the member state economies to a common monetary shock? Does unconventional monetary policy accentuate or attenuate internal imbalances within the union?

In this paper, we aim to provide both a quantitative assessment of the arguments made in the debate and some answers to the underlying academic questions. Specifically, we use vector autoregressions to study the effectiveness and side effects of unconventional monetary interventions. Our results show that the claims of both parties in the public debate are supported by the data. On the one hand, unconventional monetary policy shocks are effective at lowering public and private interest rates and increasing economic activity, consumer prices, and inflation expectations. On the other hand, the shocks lead to a rise in primary public expenditures, a divergence of consumer prices within the union, and a widening of internal trade balances. Especially the latter findings contribute to the academic debate on unconventional monetary policy, which largely focuses on the effectiveness and transmission of this policy (see below) and less on the side effects. 
The identification of causal effects associated with unconventional monetary policy raises new challenges, because identification cannot fully rely on the identification strategies developed for conventional interest rate policies (see Wright, 2012). In this paper, we achieve identification by exploiting daily data on government bond spreads computed against Germany of various euro area countries at different maturities. We extract the common component of changes in spreads around announcements of unconventional monetary policy measures by the European Central Bank (ECB). Building on the 'event study' literature (see Kuttner, 2001, or Gürkaynak et al., 2005), we view the estimated common yield variations in a narrow window around the policy announcements as a noisy measure of the exogenous components of policy decisions. We then use this measure as an instrument for unobserved unconventional monetary policy shocks in several proxy vector autoregressions (VAR) in order to estimate the average effect of the policy surprises on the macro-economy. In doing so, we follow the methodology developed by Stock and Watson (2012) and Mertens and Ravn (2013) and used by Gertler and Karadi (2015) and by Rogers et al. (2016).

Our results are as follows. Exogenous monetary expansions that lower the average two-year rate on euro area government bonds (excluding Germany) lead to a significant rise in consumer prices and output, and a significant decline of the unemployment rate in the euro area as a whole. Various measures of inflation expectations at different horizons also increase significantly. The monetary policy shocks seem to be transmitted through private and public interest rates, financial market uncertainty and risk aversion, asset prices, as well as credit conditions. All in all, the dynamics of output and consumer prices implied by our model are more similar to the behavior of these variables in empirical models for conventional interest rate policy (see Christiano et al., 1999) than in models for unconventional monetary policy identifying policy innovations as exogenous changes in central banks' balance sheets (see Gambacorta et al., 2014). Specifically, relative to balance sheet shocks, the response of output and prices in our model is slower, while the peak effects take place later and are stronger, with output leading prices.

At the same time, our estimates reveal several side effects of the monetary interventions. The fall in sovereign bond yields and public interest payments after the expansion leads to a rise in primary public expenditures. This holds on average for the euro area as a whole as well as for most, but not all, of the largest member states. When looking at individual countries and expenditure categories, the rise in primary expenditures seems to be mainly driven by increases in public consumption. Moreover, as the economies of the member countries are affected differently by the common monetary surprise and since national fiscal authorities 
respond differently, intra-euro area trade balances widen. In particular crisis-hit countries lose price competitiveness relative to Germany. Their bilateral real exchange rates appreciate, as the increase in domestic demand and prices is more pronounced in these countries.

This paper contributes to a literature on the effects of unconventional monetary policy, which has evolved around two principal approaches. The first approach uses high frequency identification and mainly assesses the contemporaneous effects of these policies on variables available at high frequency, typically financial variables. Among others, Krishnamurthy and Vissing-Jorgensen (2011), Gagnon et al. (2011), Wright (2012), Rogers et al. (2014), and Fratzscher et al. (2016) find that unconventional policies lower interest rates and term premia and increase asset prices. ${ }^{1}$ The second approach uses structural VARs and quantifies the dynamic effects on macroeconomic variables, either on a monthly or on a quarterly frequency using (combinations of) zero and sign restrictions. Ciccarelli et al. (2013), Baumeister and Benati (2013) and Kapetanios et al. (2012) identify monetary policy shocks as exogenous variations in interest rates or spreads. On the other hand, Peersman (2011), Gambacorta et al. (2014), Boeckx et al. (2014), and Weale and Wieladek (2016) isolate unexpected changes in central banks' balance sheets.

In this paper, we use high frequency data for the identification of a VAR model for unconventional monetary policy in the euro area. In doing so, we combine the two approaches discussed above, and complement the analysis of existing VAR studies that are mainly for the US and the UK. We build on Gertler and Karadi (2015), who show how the identification through external instruments allows embedding high frequency financial market data on monetary policy surprises into a structural VAR model for the US economy. ${ }^{2}$ In particular, we follow the modification of this approach by Rogers et al. (2016), who use high frequency data by combining estimates of the relative response of variables based on data at different frequencies. The authors mainly analyze the effects of US unconventional monetary policy on exchange rates, dedicating less attention to the euro area. We focus on the euro area in detail and investigate fiscal effects and country heterogeneity.

Our work also builds on Altavilla et al. (2014), who analyze the effects of selected ECB policies by studying the reaction of sovereign yields on days of policy announcements. We follow their approach of measuring the surprise component of monetary policy to construct our external instrument, but extend their framework

\footnotetext{
${ }^{1}$ Christensen and Rudebusch (2012), Hamilton and Wu (2012) and Wu and Xia (2016) use term structure models to evaluate the impact of unconventional monetary policy on yields and the macro-economy.

${ }^{2}$ Their approach is also used by Cesa-Bianchi et al. (2016) to study unconventional monetary policy for the UK.
} 
by proposing a panel setup that extracts the unexpected common variation in spreads of different countries and maturities. We view this extension as important, given the partially segmented nature of financial markets in the euro area after the financial crisis and the temporary inversion of yield curves. In addition, we use the high frequency estimates for the identification of the VAR models rather than identifying the latter with a recursive structure, as in their paper. Compared to contributions that employ central banks' balance sheets, the identification of the model through information contained in yields has the advantage of capturing the effects of monetary interventions without restricting them to their implementation. This is important because the announcement of monetary interventions is a main source of the effectiveness of monetary policy in general (see Blinder et al., 2008) and, in particular, in recent years, when central bank communication in form of forward guidance has become a main policy tool (see den Haan, 2013, Ed.).

Our work also connects to a literature on monetary and fiscal policy interactions (see Fragetta and Kirsanova, 2010, Davig and Leeper, 2011, Traum and Yang, 2011). These papers estimate DSGE models featuring shocks to both monetary and fiscal policy, with the aim of determining policy leadership regimes in the sense of Leeper (1991). More closely related to us methodologically is Rossi and Zubairy (2011). The authors include monetary and fiscal variables jointly in a VAR and recursively identify both fiscal and conventional monetary shocks in

the US. Lastly, the paper connects to a discussion on the causes and consequences of euro area imbalances (see Blanchard and Giavazzi, 2002, Chen et al., 2013, or Kang and Shambaugh, 2016). It particularly relates to Wyplosz (2013), Comunale and Hessel (2014), and Unger (2015), who stress the role of domestic demand in explaining current account imbalances.

The paper is structured as follows. In Section 2 we discuss the VAR model and identification strategy. Section 3 contains the main results for the euro area as a whole, and then for individual countries. The last section concludes.

\section{The VAR model}

\section{$2.1 \quad$ Reduced form model}

The VAR model used can be written as

$$
y_{t}=c+\Pi(L) y_{t-1}+u_{t},
$$

and refers to variables at a monthly frequency. The $k \times 1$ vector $c$ includes constant terms, the matrix $\Pi(L)$ in lag polynomials captures the autoregressive part of the 
model, and the vector $u_{t}$ contains $k$ serially uncorrelated innovations, or reduced form shocks, with $V\left(u_{t}\right)=\Sigma$ and $u_{t} \sim N(0, \Sigma)$. We use the usual lag length selection criteria to choose the number of lags and set it to two. The reduced form model is estimated on monthly data from 1999M1 to 2015M6. We start the sample with the introduction of the euro to capture the relations between variables in the monetary union. Identification of the unconventional monetary policy shock, however, will rely only on data in the period starting from which which unconventional measures was carried out, that is, from 2007M8 to 2015M6.

We employ different specifications for the endogenous variables in $y_{t}$. In the baseline specification, $y_{t}$ includes the six variables discussed below, which refer to euro area aggregates. In the remaining specifications, $y_{t}$ includes the baseline variables plus one additional variable, which changes across specifications, ranging from measures of inflation expectations to financial variables, fiscal variables and others, both at a euro area level and for single countries. In adding one additional variable at a time, we follow Gertler and Karadi (2015) who use this approach of modifying the marginal variable in a baseline VAR. We follow their approach, which is particularly flexible and does not require a Bayesian perspective, a Panel VAR, or Factor structure to deal with the curse of dimensionality.

The variables included in the baseline specification are

$$
y_{t}=\left(\begin{array}{c}
\text { Two-year rate on euro area government bonds } \\
\text { Stock market volatility } \\
\log (\text { Credit to non-financial firms }) \\
\log (\text { Harmonized index of consumer prices }) \\
\log (\text { Interpolated GDP }) \\
\text { Unemployment rate }
\end{array}\right) .
$$

These variables capture financial and interest rate conditions, prices, as well as measures of real economic activity. As a variable reflecting the stance of monetary policy, i.e. a 'policy indicator', we use a weighted average of the two-year rates on government bonds for nine euro area countries excluding Germany. ${ }^{3}$ In using a (medium-term) government bond rate as policy indicator in a VAR identified with an external instrument, we follow Gertler and Karadi (2015) who employ the one-year US treasury rate. Compared to the short-term interest rates typically used in VAR studies on conventional monetary policy, the variable used has the

\footnotetext{
${ }^{3}$ The countries are Austria, Belgium, Finland, France, Ireland, Italy, Netherlands, Portugal, and Spain. We exclude German bonds since they played a particular role as a safe haven asset during the euro crisis, whereas for bonds of other euro area countries it is less clear whether they are considered as safe haven assets (see, for example, Altavilla et al., 2014 or Fratzscher et al., 2016).
} 
advantage of taking into account non-standard policy innovations, which are aimed at influencing expectations and yields at longer horizons. Moreover, short-term interest rates like the Eonia or the Euribor would be less suitable because they are constrained by the zero lower bound in our sample. In contrast, the two-year bond rates used is less constrained by the zero lower bound, which it crosses only at the very end of our sample.

In addition to the consumer price index (CPI) and the real output variable commonly included in monetary VAR models, we also add a measure of equity market volatility. Specifically, we include the VStoxx volatility index, which is based on option prices of stocks in the EuroStoxx 50. We do so to capture the relation between sovereign bond rates, financial stress, and monetary policy during the identification period, as several non-standard ECB measures were triggered by financial market developments or were specifically aimed at reducing financial risk and uncertainty in the euro area (see Boeckx et al., 2014). Moreover, we add credit to non-financial firms to the model as, for instance, long-term refinancing operations of the ECB, which constitute an important share of the unconventional measures in our sample, have the purpose of stimulating bank lending. Lastly, as a measure of labor market slack and inflation pressure, we include the unemployment rate, since the ECB's large-scale asset purchase programs are specifically targeted at lifting prices and inflation expectations. Appendix A contains details on all variables used in the different specifications and their construction.

The VAR innovations are assumed to be linearly driven by a non-standard monetary policy shock $\epsilon_{t}^{m}$, which we aim to identify, and other structural shocks $\epsilon_{t}^{*}$, which are of no interest for the purpose of this paper. The VAR innovations $u_{t}$ are related to structural shocks $\epsilon_{t}^{m}$ and $\epsilon_{t}^{*}$ through

$$
u_{t}=b^{m} \epsilon_{t}^{m}+B^{*} \epsilon_{t}^{*}
$$

The $k \times 1$ vector $b^{m}$ captures the impulse vector to a monetary shock of size 1 and is required to generate impulse responses.

Our identification strategy follows the variant of Rogers et al. (2016) of the identification with external instruments developed by Stock and Watson (2012) and Mertens and Ravn (2013) and its adaption to monetary policy by Gertler and Karadi (2015). Under the condition of a variable $m_{t}$ being available such that

$$
\begin{gathered}
E\left(m_{t} \epsilon_{t}^{m}\right) \neq 0, \\
E\left(m_{t} \epsilon_{t}^{*}\right)=0,
\end{gathered}
$$

Stock and Watson (2012) and Mertens and Ravn (2013) show how to consistently 
estimate an impulse vector $\tilde{b}^{m}$, which differs from $b^{m}$ only up to a scalar $\mu$, by exploiting the correlation between $m_{t}$ and the estimated VAR residuals. Estimating $\tilde{b}^{m}$ is sufficient to compute the relative responses of the variables in the system $\left(\tilde{b}_{j}^{m} / \tilde{b}_{i}^{m}=b_{j}^{m} / b_{i}^{m}\right)$ and can be used to obtain impulse responses to a pre-scaled shock to the policy indicator. Building on this methodology, Rogers et al. (2016) use the event-study approach and employ high frequency data, not aggregated to a monthly level, in order to refine the estimation of the relative response of the endogenous variables.

We first discuss how we compute a measure, $m_{t}$ (henceforth referred to as instrument or proxy), correlated with the unconventional monetary policy shock for the euro area. We then discuss our identification approach, given $m_{t}$, in detail.

\subsection{A proxy for monetary policy shocks}

To construct a proxy $m_{t}$ for unconventional monetary shocks, we build on Kuttner (2001) and the subsequent literature that uses high frequency data in an event study manner. In general, this approach focuses on one or more selected financial indicators, directly or indirectly associated with the policy rate. It postulates that the price of the indicator closely before a monetary announcement already incorporates the (expected) endogenous response of monetary policy to the state of the economy. Accordingly, any variation in this price from before to after the announcement reflects an exogenous and unexpected component of monetary policy revealed by the announcement and, consequently, is interpreted as exogenous with respect to the economy (see Gürkaynak et al., 2005, for a discussion).

The proxy $m_{t}$ is not required to be a correct measure of monetary shocks, as several forms of measurement error can be accounted for (see Mertens and Ravn, 2013). To construct a measure correlated with monetary policy shocks, we build on Altavilla et al. (2014) and use daily data on euro area government bond yields. In particular, we extract the common variation in sovereign spreads to Germany for different maturities of several crisis-hit countries around relevant monetary policy announcements by the ECB. Thereby, we extend the analysis of Altavilla et al. (2014) to a panel dimension across countries and maturities. Moreover, we use spreads instead of yields, following Rogers et al. (2016).

Specifically, we employ the regression

$$
x_{i j t}=\alpha_{i}+\beta x_{i j t-1}+\sum_{a=1}^{A} \gamma_{a} D_{a t}+\sum_{n=1}^{N} \delta_{n} z_{n t}+\eta_{i j t},
$$

on a daily frequency. In (4), $x_{i j t}$ represents the sovereign bond spread versus 
Germany of country $i$ on maturity $j$ at time $t, \alpha_{i}$ are country-specific constants, $D_{a t}$ represents a dummy variable taking value 1 if the unconventional monetary policy announcement $a=1, . ., A$ took place at day $t$, otherwise zero, and $z_{n t}$ controls for the release of macroeconomic news on variable $n=1, . ., N$. We include 139 macroeconomic news variables in $z_{n t}$, computed as the surprise component in economic data releases for the euro area, the UK, and the US, to attenuate the risk that the one day windows cover realizations of structural shocks that differ from the shocks of interest. ${ }^{4}$

The key coefficients in (4) are the estimated $\gamma_{a}$ 's. They capture the common variation in spreads in response to ECB announcement $a$. The vector $\left(\gamma_{1}, . ., \gamma_{A}\right)^{\prime}$ is transformed into one daily series $m_{t}^{D}$, taking value zero for non-announcement days and value $\gamma_{a}$ on the day of announcement $a$. We then turn $m_{t}^{D}$ into a monthly series $m_{t}^{M}$ by summing within months. Both $m_{t}^{D}$ and $m_{t}^{M}$ will be used for identification, after winsorizing them at $80 \%$ to control for outliers. ${ }^{5}$

We use $A=32$ announcement days. They correspond to the days in which the ECB made explicit or implicit reference (either during regular meetings or other relevant speeches and communication) to at least one of the following three nonstandard policy measures: forward guidance, credit easing, or quantitative easing. The choice of events closely follows Wright (2012) and Rogers et al. (2014), but are extended to include events through summer 2015. Since at the time of writing, in 2016, the sample of ECB unconventional monetary policy announcements is still relatively short, we do not distinguish among the precise types of monetary interventions, but aim at estimating the average effect of the measures. The first relevant event for our analysis occurred on August 22, 2007, the last one on January 22, 2015. The events comprise, for instance, announcements of long-term refinancing operations (LTROs), the securities market program (SMP), and outright monetary transactions (OMT). Appendix A contains the full list of events.

To estimate (4), we use spreads of four countries and three maturities. Specifically, we use spreads of Ireland, Italy, Portugal, and Spain. We chose these countries because most of the non-standard measures in our sample were especially aimed at affecting the yields of these member states rather than those of Germany or other countries that were hit less by the crisis. For example, all four countries were covered by the SMP. ${ }^{6}$ Regarding maturities, we use spreads for two, five, and

\footnotetext{
${ }^{4}$ For each variable, we construct a daily time series as the difference between the firstreleased data and the expected values, the latter corresponding to the median estimate of a panel of experts surveyed by Bloomberg.

${ }^{5}$ In the sensitivity analysis, we show that our results are qualitatively and also quantitatively relatively similar if we use the non-winsorized shock series.

${ }^{6}$ Greece was also contained in the SMP, but we exclude it from the estimation because
} 
ten years for two reasons. First, compared to bonds with longer maturity, these segments are typically more liquid, especially for the two smaller countries in the panel. Second, compared to bonds with shorter maturity, these segments are less constrained by the zero lower bound and, thus, provide more variation. We also select these countries and maturities because bonds and respective data are available throughout the full sample. We consider yields for different maturities rather than only for one maturity because the yield curve of all four countries was inverted at some point during the euro area debt crisis, when several important non-standard measures were announced. The inversion of the curve makes it a priori difficult to determine which maturity best reflects the announced interventions; hence our use of several maturities. Finally, we use spreads instead of levels mainly to eliminate the effect of policy rate changes on the level of yields. ${ }^{7}$

\subsection{Identification of the structural VAR}

Having constructed a daily and a monthly measure correlated with unconventional monetary policy shocks, we now discuss how we use them for the identification of the structural VAR. Stock and Watson (2012) and Mertens and Ravn (2013) propose to identify the VAR using the regression

$$
\hat{u}_{j t}=\alpha+\beta_{i} m_{t}+\eta_{j t}, \quad i=1, \ldots, k
$$

where $\hat{u}_{j t}$ is the estimated VAR reduced form residual corresponding to equation $j$ of model (1), and $m_{t}$ is the instrument for $\epsilon_{t}^{m}$ at the same frequency as $\hat{u}_{j t}$. From these regression, the relative contemporaneous response of the variables in the VAR, $b_{j}^{m} / b_{i}^{m}$, can be obtained with $i$ denoting the equation in which the policy indicator enters as dependent variable. ${ }^{8}$ In other words, given equations (2) and (3), $m_{t}$ allows for a consistent estimation of the relative contemporaneous response of the variables in the VAR to an unconventional monetary policy shock that changes the policy indicator by a scaled amount.

Furthermore, we follow Rogers et al. (2016) and use the event-study approach

its sovereign bonds were restructured in 2010 and because of a lack of data on two- and five-year yields.

${ }^{7}$ In the impulse response analysis below, we check that interest rates closely tied to the main refinancing rate of the ECB, such as the Euribor or Eurepo, do not react on impact to the identified policy innovations, supporting our interpretation that the latter reflect non-standard measures.

${ }^{8}$ The approach exploits the fact that, under equations (2) and (3), $E\left(u_{t} m_{t}\right)=$ $b^{m} E\left(\epsilon_{t}^{m} m_{t}\right)$, hence $\hat{\beta}_{j} \stackrel{p}{\rightarrow} b_{j}^{m} \mu$ with $\mu=E\left(\epsilon_{t}^{m} m_{t}\right) / E\left(m_{t}\right)$ constant across $j$, and thus $\hat{\beta}_{j} / \hat{\beta}_{i} \stackrel{p}{\rightarrow} b_{j}^{m} / b_{i}^{m}$. 
on high frequency data to refine the estimation of the relative contemporaneous response of the variables in the system. In a regression of the type

$$
\Delta v_{t}=\gamma_{1}+\gamma_{2} \Delta r_{t}+\nu_{t}
$$

with $\Delta v_{t}$ the first difference of a variable of interest and $\Delta r_{t}$ the first difference of the policy indicator, the estimation of $\gamma_{2}$ is usually inconsistent since $\Delta r_{t}$ is endogenous. The event-study approach exploits the fact that a consistent estimate can be obtained if the periods in which $\Delta r_{t}$ is exogenous can be isolated and that only those sub-periods are used in the regression (for an application, see Gürkaynak et al., 2005, and Ehrmann and Fratzscher, 2005). In our application, these periods are the days of monetary policy announcements, so that we obtain a measure of exogenous variations in $\Delta r_{t}$ on these days - our instrument $m_{t}^{D}$. The first best approach would then be to have data on the same daily frequency for all the variables included in the VAR, as this would allow estimating the relative contemporaneous effect of a structural shock of interest on all variables using (6).

However, daily data are only available for a subset of variables. We hence estimate $\beta_{j}$ in model (5) with two separate types of regressions, in order to make use of high frequency data, whenever available. For variables $y_{j t}$ available at a daily frequency, we estimate the corresponding element $\beta_{j}$ by replacing the dependent variable in (6) with the daily first difference of the variable of interest, and by replacing the regressor with the daily series $m_{t}^{D}$. For variables $y_{j t}$ not available at a daily frequency, we approximate the unobserved high frequency first difference of the variable with the VAR innovation $\hat{u}_{j t}$ at a monthly frequency and use the monthly series $m_{t}^{M}$ as regressor, as outlined above. In the baseline specification, for instance, we compute the variation on the daily frequency for the first two variables, namely the two-year rate and the VStoxx.

Equation (5) and its equivalent at the daily frequency allow for an assessment of the strength of our instrument. We find that $m_{t}$ is a strong instrument for our policy indicator. The $F$-statistic equals 40.39 and the $\beta_{j}$ is positive. The high $F$-statistic suggests that a weak instrument problem is unlikely. ${ }^{9}$

\section{Results}

We discuss the effects of unconventional monetary policy using estimated impulse responses to a monetary policy innovation. The responses are reported along with

\footnotetext{
${ }^{9}$ The alternative monetary policy indicators considered in the sensitivity analysis are the five- and ten-year yield on euro area sovereign bonds excluding Germany. The Fstatistics for these two indicators are 40.83 and 34.74 , respectively.
} 
their 90 percent confidence bands based on bootstrapping. ${ }^{10}$ In all models, the shock is scaled to lower the average two-year rate on euro area bonds by 25 basis points. We first discuss the effectiveness and transmission of the monetary shock, then turn to the fiscal side effects, before finally evaluating the effects on countryspecific variables, relative prices, and trade balances.

\subsection{Effectiveness}

Figure 1 reports the impulse responses for the baseline VAR. The two-year rate drops on impact, as imposed, then remains significantly below trend for several months, before overshooting slightly after about one year. This surprise expansion leads to a significant and long-lasting reduction in risk aversion and uncertainty, as measured by the VStoxx. The volume of credit to non-financial corporations increases and reaches a peak after three years. These responses are associated with a gradual increase in consumer prices and GDP, with output peaking after about 18 months, slightly earlier than prices. The price dynamics are consistent with the overshooting in the two-year rate as an endogenous reaction of monetary policy. The responses of prices and output are also mirrored in the dynamics of the unemployment rate, which bottoms after approximately two years, before returning to the level where it would have been without the monetary innovation.

Overall, the results are qualitatively in line with existing evidence on the effects of unconventional monetary policy shocks, but reveal several noteworthy quantitative differences. In Gambacorta et al. (2014), Boeckx et al. (2014), and Weale and Wieladek (2016), who identify policy surprises as shocks to central banks' balance sheets, output and prices respond faster, peaking approximately six to twelve months earlier, and reach their maximum simultaneously. Instead, we find a more sluggish response of both variables, peaking only after roughly two years, and with output leading prices. Interestingly, the dynamics implied by our estimates are more similar to responses to conventional monetary policy shocks (see Christiano et al., 1999, or Gertler and Karadi, 2015).

Regarding the effectiveness of monetary policy, our results are likewise more similar to the effects of conventional monetary policy. Gertler and Karadi (2015) find that in the US a shock to the one-year government bond rate of 20 basis points induces a maximum decline of output and prices of approximately 0.5 and 0.1

\footnotetext{
${ }^{10}$ We apply a fixed-design wild bootstrap, as in Mertens and Ravn (2013) and Gertler and Karadi (2015). In principle, this procedure accounts for estimation errors in both stages of the structural VAR estimation (equations 1 and 5). For the variables identified on a daily frequency, however, the bootstrap procedure does not apply in the identification stage. Therefore, no confidence bands regarding the immediate impact are reported for these variables.
} 
Figure 1: Baseline model for the euro area
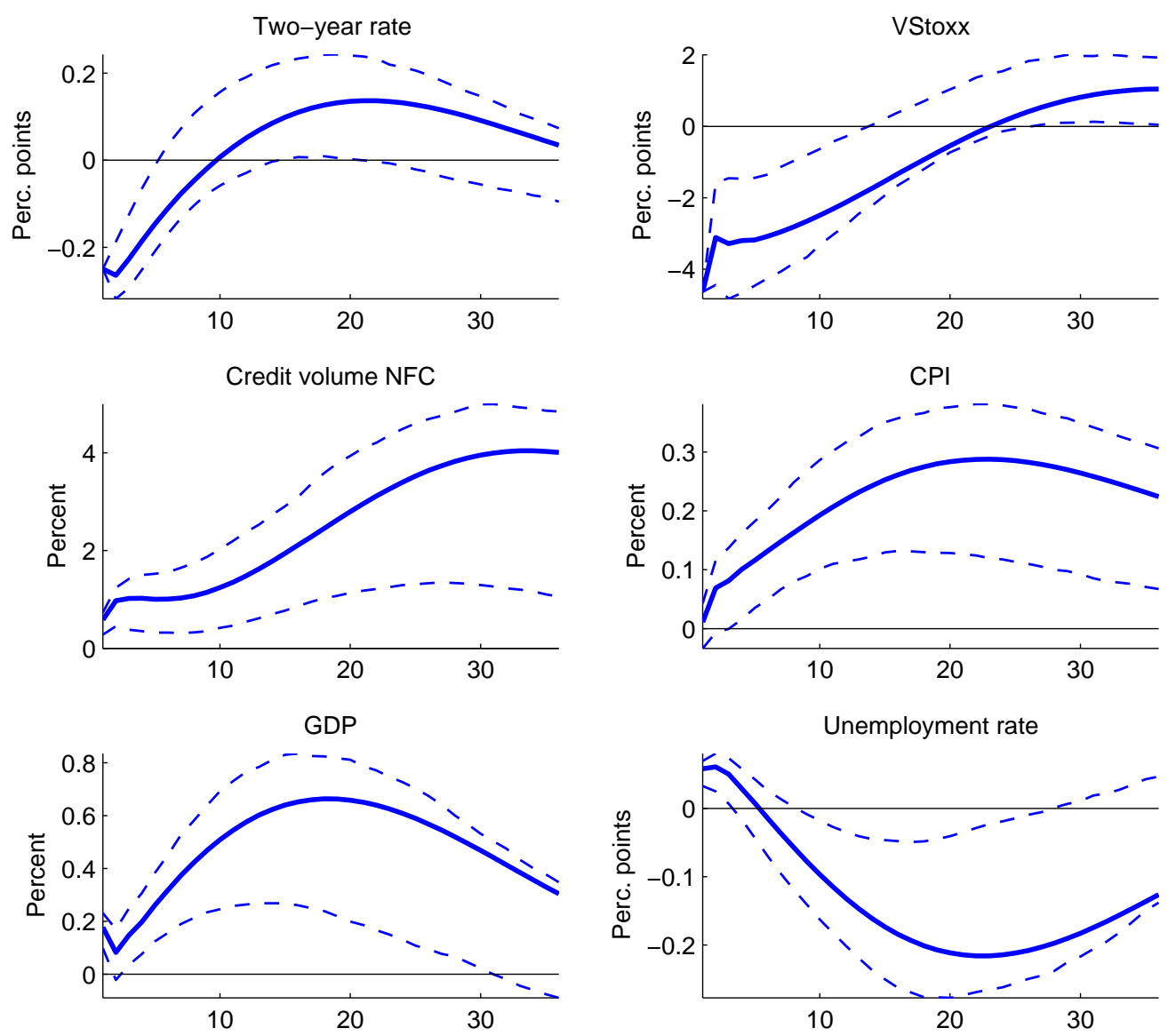

Note: The figure shows the estimated impulse responses, along with their 90 percent confidence bands, obtained using 500 bootstrap replications, of selected euro area variables to a monetary policy shock that lowers the average two-year rate by 25 basis points. The sample is 1999M1 through 2015M6.

percent, respectively. Even though the effect on prices is only marginally significant in their case, while it is highly significant in our case, these point estimates are close to ours if we consider a contractionary shock. In contrast, the effects of comparably sized balance sheet shocks tend to be smaller. According to the estimates of Gambacorta et al. (2014), for example, a shock to central bank assets that lowers the VIX by one percentage point on impact has a peak effect on output and prices that is less than half of what we find if we rescale our shock to the two-year rate such that it lowers the VStoxx by one percentage point on impact.

We next evaluate the effects of the monetary surprise on several measures of inflation expectations, selected interest rates, and the Euro-Dollar exchange rate. Inflation expectations are a key determinant of actual inflation and interest 
and exchange rates represent important variables in the monetary transmission mechanism. Figure 2 contains the results. As outlined above, for this and all the following analyses, we augment the benchmark six-variable VAR with one additional variable at a time, and combine the responses of the marginal variables into one graph. ${ }^{11}$ The figure shows the responses of two monthly survey-based measures of inflation expectations. The first is a survey of financial market experts, who are asked for their inflation expectations for the euro area over the next six months. The differential between the share of analysts who expect to see a rising inflation rate and the percentage who anticipate a falling inflation rate widens significantly five months after the shock, by about five percentage points. The survey is conducted by Centre for European Economic Research (ZEW). The second measure is a survey of consumers, which assesses inflation expectations over a horizon of twelve months. The second survey is conducted by the European Commission. Inflation expectations increase as well according to this measure, but the rise is statistically insignificant.

The next two panels show the responses of two financial market-based measures of inflation expectations. The two-year swap rate increases significantly and rapidly in response to the shock. The behavior of the one-, five-, and ten-year swap rates are deferred to Figure 7 in Appendix B. While all responses are qualitatively similar, swap rates for shorter maturities react more strongly and the effects last longer. From the impulse response of the five- and ten-year swap rate, we compute the five-year, five-year forward inflation swap rate, which has been one of the ECB's preferred measures of inflation expectations in recent years. Figure 2 shows that this indicator also increases significantly on impact, by about five basis points, and stays above trend for two months.

In the remaining panels, we analyze selected variables through which unconventional monetary policy surprises are potentially transmitted to the economy. The average ten-year rate on euro area government bonds (excluding Germany) and the term spread, defined as the difference between the response of the ten-year rate and the three-month Eurepo, both decline significantly on impact and stay below trend for roughly half a year. The exchange rate, on the other hand, appreciates. The latter finding is in line with Rogers et al. (2016) and can be rationalized by a reduction in break-up premia. The effect is relatively small, however. Finally, the insignificant response of the three-month Eurepo upon impact supports our

\footnotetext{
${ }^{11}$ Note that the sample may change depending on the marginal variable included. In particular, data on inflation swap rates is available only from 2008M9 onward, which considerably reduces the sample. The corresponding results for these variables should, thus, be treated cautiously. The figure notes contain details on the sample lengths for all estimations.
} 
Figure 2: Inflation expectations, interest rates, and Euro-Dollar exchange rate
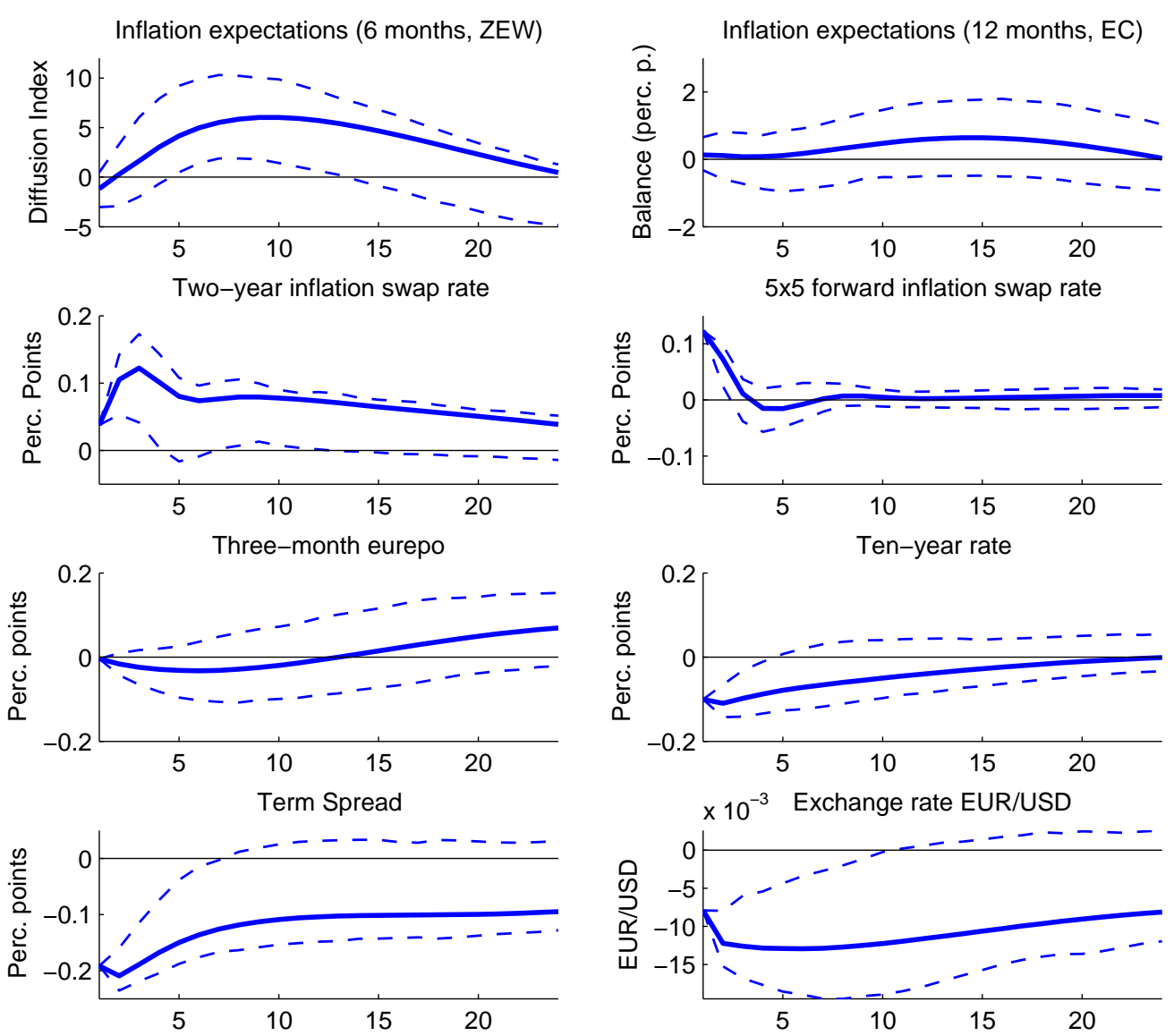

Note: The figure shows the estimated impulse responses, along with their 90 percent confidence bands, obtained using 500 bootstrap replications, of selected euro area variables to a monetary policy shock that lowers the average two-year rate by 25 basis points. The sample is 2008M9 through 2015M6 for the swap rates and 1999M1 through 2015M6 for the other variables.

identification strategy of using yield spreads in the first-stage regression instead of levels. It indicates that the identified monetary innovations reflect unexpected unconventional policy actions orthogonal to conventional policy rate changes.

Figures 8-10 in Appendix B report the responses of further variables that provide additional insights and support our main results. Figure 8 shows that the real expansion is not limited to GDP but extends to alternative measure of real activity. Figure 9 shows that interest rates and asset prices in many other financial market segments are also affected by the shock, with stronger effects on rates of shorter maturities and riskier assets. Figure 10 shows that the monetary surprise expansion is associated with increases in credit volume and declines in credit rates 
for both households and non-financial corporations.

As a final step in this subsection, we evaluate the sensitivity of the baseline model to several alterations. Appendix B contains the corresponding figures 1113. First, we show that the responses of the six baseline variables change only slightly when adding the different marginal variables considered so far. ${ }^{12}$ Second, we compute impulse responses without winsorizing the instrument before identification. The results are qualitatively and quantitatively similar to the baseline results. Then, we include Germany into the computation of the average euro area two-year rate. The responses are more pronounced, given that the scale of the shock is the same and that German yields are less sensitive to the shock. Last, we use the five- or ten-year rate as policy indicator, instead of the two-year rate. The reaction of the baseline variables is relatively similar across specifications. Intuitively, the effects are stronger when yields for longer maturities unexpectedly drop by 25 basis points. All in all, the baseline results suggest that non-standard monetary surprise interventions by the ECB are effective in lifting economic activity, consumer prices, and inflation expectations.

\subsection{Fiscal side effects}

Next, we assess whether the identified monetary surprises have fiscal consequences. Such potential side effects are a primary concern of policymakers in many member countries, in the European Commission, as well as in the ECB itself (see Schmidt et al., 2015, Weidmann and Knot, 2015, Liikanen, 2015, Commission, 2015, ECB, 2015). In particular, possible windfall gains, that is, savings on lower than expected public interest payments, are viewed as potentially generating skewed incentives and reducing governments' consolidation efforts. According to their 2013 country stability programs, for example, all of the four largest member states and Portugal planned reductions in the ratio of primary expenditure to GDP, ranging between 0.5 percentage points in Germany and 6.4 in Spain (see Table 1). However, according to the European Commission's assessment of the stability programs in 2015, all countries missed their target. At the lower end, Germany missed it by 0.7 percentage points and, at the higher end, Portugal by 2.6 percentage points. While there are several possible explanations for these misses, we assess whether there is evidence that unexpectedly lower government yields lead to lower public interest expenditures and higher public primary expenditures.

We start with an analysis for the euro area as a whole, using GDP weighted

\footnotetext{
${ }^{12}$ The figure shows the response of the baseline variables when adding the marginal variables contained in Figures 2, 3, 8, 9, and 10, except for inflation swaps rates. For the latter, in fact, the data start only in 2008.
} 
Table 1: Planned versus actual reduction in primary public expenditures 20122015 (change in percentage points of GDP)

\begin{tabular}{lccc}
\hline Country & $\begin{array}{c}\text { Stability program } \\
\text { planned in 2013 }\end{array}$ & $\begin{array}{c}\text { Reduction assessed in } \\
\text { stability programs 2015 }\end{array}$ & Difference \\
\hline Germany & -0.5 & 0.2 & 0.7 \\
Spain & -6.4 & -5.1 & 1.3 \\
France & -1.2 & 0.6 & 1.8 \\
Italy & -1.6 & 0.7 & 2.3 \\
Portugal & -3.1 & -0.5 & 2.6 \\
\hline
\end{tabular}

averages. The first four panels in Figure 3 show the behavior of the overall budget, the debt ratio, revenues, and expenditures. Consistent with standard theory, the average government balance in the euro area improves following the monetary surprise stimulus that lowers sovereign yields and raises output and prices. The maximum response occurs after about one year and equals 2.5 billion euro. After about another year, however, the balance undershoots significantly. Due to the increase in output, the debt to GDP ratio nevertheless improves significantly. It declines by nearly one percentage point around two years after the shock. Decomposing the dynamics of the overall budget into changes in revenues and expenditures shows that revenues increase significantly as output exceeds trend. In line with conventional theory of automatic stabilizers (see Van den Noord, 2000), they thereby contribute to the improvement in the overall budget seen over the first two years after the shock. A quantitative comparison of the responses of revenues and GDP (see Figure 1) shows that there is nearly a one-to-one relationship between the two variables. This number is consistent with official estimates of the elasticity of revenues with respect to the output gap of unity in OECD countries.

The response of expenditures, on the other hand, is difficult to reconcile with the theory of automatic stabilizers. The official estimate of the elasticity of expenditures to the output gap in the euro area is -0.1 (see Girouard and André, 2006). This value would predict a small decline in expenditures when output increases. Moreover, in the special case of an interest rate shock that raises output, spending is expected to decline somewhat more strongly as public interest payments are likely to fall. In sharp contrast, the response of expenditures to the shock shows a strong, persistent, and mostly significant increase over a horizon of roughly four years. This finding rationalizes the undershooting of the overall balance and suggests that, on average across countries, fiscal policy is actively responding to non-standard monetary policy innovations in a procyclical manner.

The bottom four panels decompose the dynamics of total expenditures into 
Figure 3: Government budget balance, debt, and expenditure by category
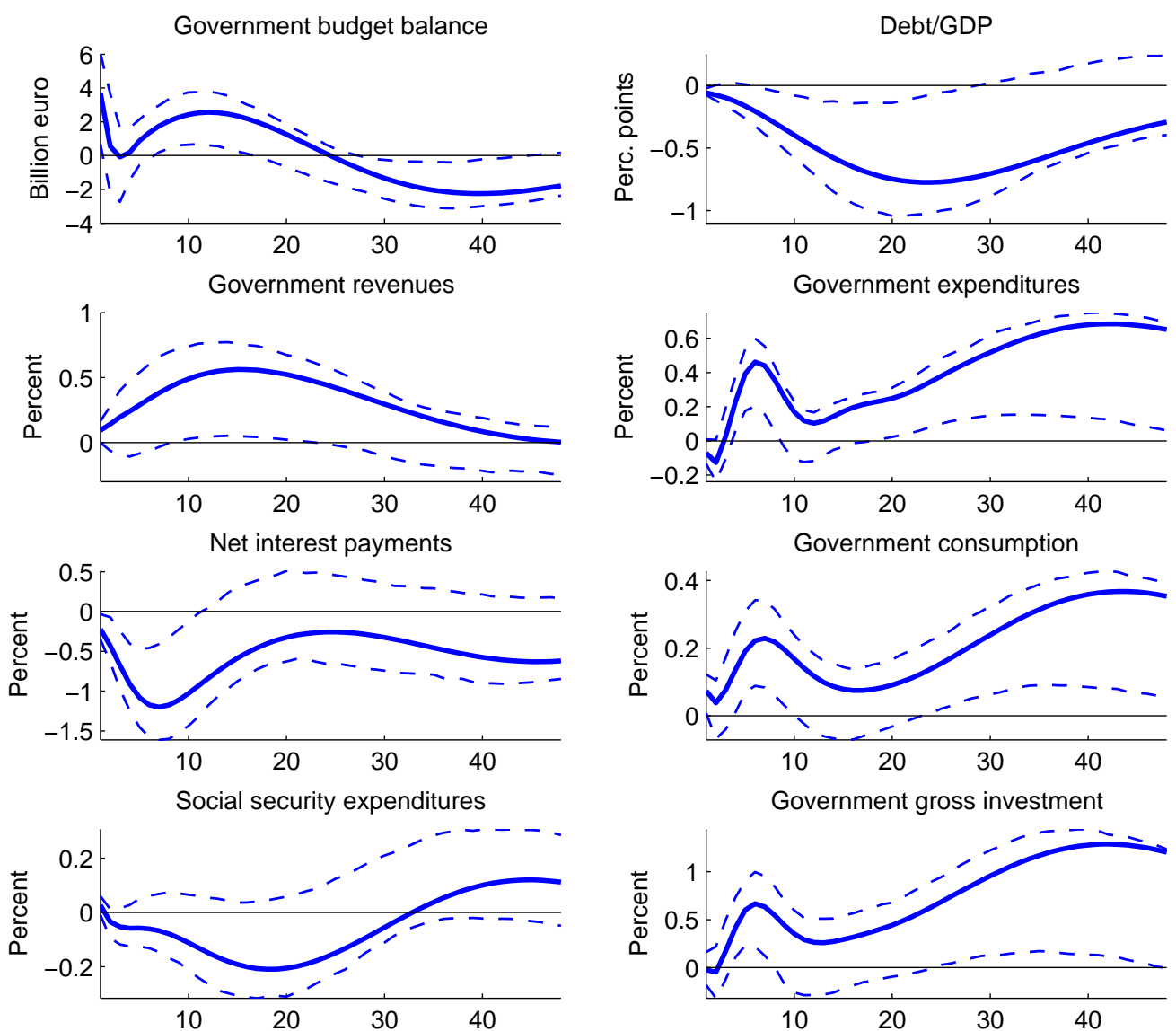

Note: The figure shows the estimated impulse responses, along with their 90 percent confidence bands, obtained using 500 bootstrap replications, of selected euro area variables to a monetary policy shock that lowers the average two-year rate by 25 basis points. The sample is 2003M1 through 2015M6 for the budget balance, 2000M1 through 2015M6 for debt/GDP, 2000M3 through 2015M6 for revenues and expenditures, and 2002M3 through 2015M6 for the detailed expenditure categories.

those of its components. As expected, the expansionary monetary shock leads to a significant reduction of net interest payments, which fall for about one year. The unanticipated drop in interest payments, in turn, is associated with a persistent increase in government consumption. Together, the two responses suggest that windfall profits from unexpectedly lower interest expenditure are partly used to increase intermediate good consumption and compensation of public employees. There is also some evidence of an increase in public investment. The latter is consistent with the decline in public interest rates, which renders public investments more profitable. Social security contributions, on the other hand, tend to fall as 
output rises and as the unemployment rate declines. Although it is not statistically significant, the decline in social expenditures is in line with the notion of automatic stabilizers on the spending side working mostly through unemployment benefits and age- and health-related outlays (see Darby and Melitz, 2008).

To quantify the average economic relevance of monetary policy shocks for the evolution of the different expenditure components we compute forecast error variance decompositions. Specifically, Table 2 shows the percentage contribution of the monetary shock to the variance of the four spending categories. As fiscal policy responds only relatively slowly to the monetary shocks, the latter explain only a small fraction of the variability of the expenditure categories at shorter horizons. For longer horizons, however, they are a relevant driver of public expenditures. They account for between one fourth and one third of the forecast error variance at the 24-month horizon. Intuitively, they are particularly important for net interest payments and investment. However, they also explain 24 percent of the variability in government consumption.

Table 2: Percentage contribution of monetary policy shock to forecast errror variance of public expenditures (monthly horizon)

\begin{tabular}{lcccc}
\hline Horizon & $\begin{array}{c}\text { Net interest } \\
\text { payments }\end{array}$ & $\begin{array}{c}\text { Government } \\
\text { consumption }\end{array}$ & $\begin{array}{c}\text { Social security } \\
\text { expenditures }\end{array}$ & $\begin{array}{c}\text { Government } \\
\text { investment }\end{array}$ \\
\hline 1 & 2 & 3 & 2 & 2 \\
6 & 2 & 2 & 2 & 4 \\
12 & 13 & 12 & 11 & 19 \\
24 & 34 & 24 & 22 & 36 \\
\hline
\end{tabular}

Since, in the euro area, revenues and spending are largely determined at the member state level, we next study commonalities and differences in the response of fiscal policy to the common monetary surprise across member states. To focus the discussion, we concentrate on three countries that were heavily and persistently affected by the sovereign debt crisis, Italy, Portugal, and Spain, as well as the two largest euro area economies, France and Germany. Combined, these countries provide a comprehensive picture of fiscal dynamics in the euro area as they account for more than $80 \%$ of the union's GDP. Moreover, we concentrate on the effects on government consumption as this is the most controversially discussed expenditure category in the public debate, other than public investment, and more directly controlled by the national fiscal authorities, unlike net interest payments or social security outlays. ${ }^{13}$

\footnotetext{
${ }^{13}$ Figure 15 in Appendix B shows the responses of all four expenditure categories in the different countries for completeness.
} 
Figure 4 shows the peak effects of government consumption for the five countries following the expansionary monetary policy shock. They are all statistically significant. They are also economically relevant. At the maximum, public consumption increases by about one percent above trend in Spain and Portugal. In Italy and France it rises by roughly one half of a percent. In contrast, in Germany government consumption declines by approximately one half of a percent. Overall, these reactions are in line with the country-specific responses of sovereign yields to the common monetary shock (see next section). Sovereign yields decrease for Italy, Portugal, and Spain and tend to slightly increase in Germany and France.

Figure 4: Peak response of government consumption

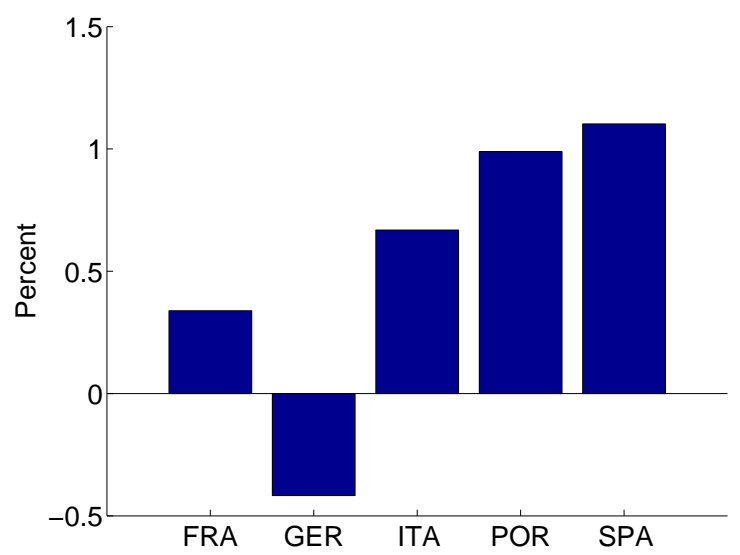

Note: The figure shows the estimated peak impulse responses of government consumption in selected countries to a monetary policy shock that lowers the average two-year rate on euro area government bonds by 25 basis points. The sample is $2002 \mathrm{M} 3$ through 2015M6 for Germany and 1999M1 through 2015M6 for the other countries.

\subsection{Country heterogeneity and internal (im)balances}

As a final step in the analysis, we investigate whether there is further evidence of heterogeneity in the reaction of the five economies to the common shock and whether the heterogeneous responses translate into relative price changes and movements in intra-union trade balances. Figure 5 contains the estimated peak effects of the monetary policy shock on country-specific two-year rates, benchmark local stock market indexes, GDP, and CPI. ${ }^{14}$ All peak effects are statistically different from zero.

\footnotetext{
${ }^{14}$ The stock prices can also be understood as mirroring the development of uncertainty and risk aversion on a country level, with an inverted sign, as country-specific volatility indexes are not available for all countries. Figure 16 in Appendix B shows the full responses of all four variables for all countries.
} 
Figure 5: Peak responses of country-specific variables
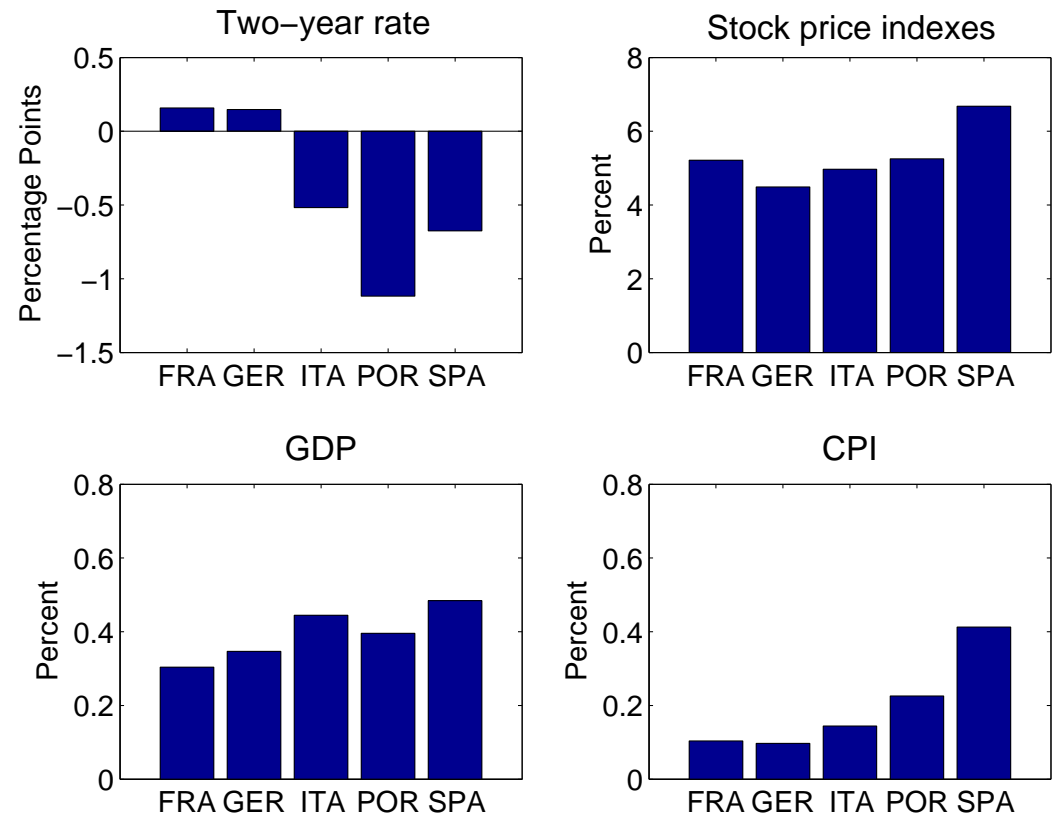

Note: The figure shows the estimated peak impulse responses of government consumption in selected countries to a monetary policy shock that lowers the average two-year rate on euro area government bonds by 25 basis points. The sample is $2000 \mathrm{M} 1$ through 2015M for the stock indices and 1999M1 through 2015M6 for the other variables.

The figure shows a contrast between the maximum responses of the sovereign yields in France and Germany on the one hand, and Italy, Portugal and Spain on the other hand. While yields increase in the former two countries, they decrease in the latter three. In the two largest economies the two-year rate rises by about 10 basis points. This positive-rather than negative-reaction of yields can be explained by at least two factors. First, government bonds of both countries were seen as a safe haven in euro-denominated securities markets, in particular during the height of the European debt crisis. As the non-standard policy interventions reduced uncertainty and increased risk appetite, the demand for safe-haven assets declined. Second, several of the policy measures contained in our sample most likely also affected the perceived risk of a break-up of the euro area. They thereby reduced revaluation risks contained in these bond prices.

In stark contrast, yields sharply decline by about 40, 60, and 100 basis points for Italy, Spain, and Portugal, respectively. This strong negative reaction to the common shock seems to be one relevant factor underlying the larger increase in primary expenditures in these three countries. Moreover, the huge drop in yields is associated with strong increases in equity prices, output and consumer prices. 
The responses of these variables are more pronounced than in France or Germany. In Spain, for example, the peak response of output and prices is about one half of a percent. Nevertheless, the peak responses of equity prices, GDP and consumer prices in France and Germany show that these two countries also profit from the expansionary monetary shock, despite the increase in sovereign yields. This observation suggests that other forces might also be at play.

Figure 6: Bilateral real exchange rates and trade balances
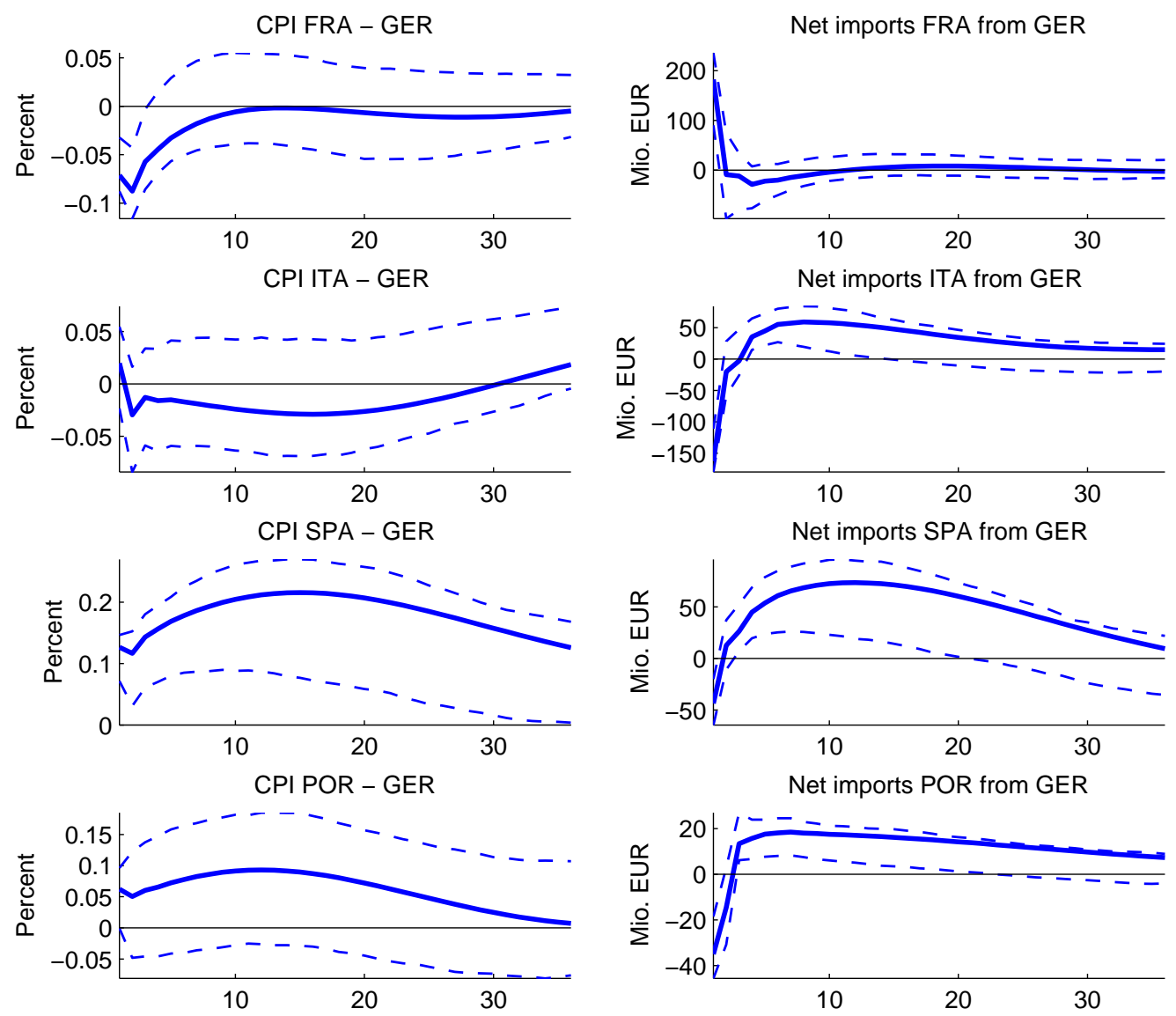

Note: The figure shows the estimated impulse responses, along with their 90 percent confidence bands, obtained using 500 bootstrap replications, of selected countryspecific variables to a monetary policy shock that lowers the average two-year rate by 25 basis points. The sample is 2001M1 through 2015M6 for the net imports and 1999M1 through 2015M6 for the CPI differences.

Specifically, relative price and demand developments within the monetary union might affect intra-euro area trade balances and thereby GDP. They may increase in particular surpluses in Germany, which is a large net exporting country, and deficits in other countries. We investigate this issue next. Figure 6 shows 
the responses of the CPI-difference of France, Italy, Portugal, and Spain relative to Germany; that is, the CPI based bilateral real exchange rates, together with the dynamics of the respective bilateral trade balances. While bilateral exchange rates seem largely unresponsive in France and Italy, they increase in Portugal and Spain. Relative prices in Spain rise significantly on impact and for more than two years. The maximum response is 0.2 percent after about 18 months. For Portugal, relative prices to Germany also increase, but the effect is less pronounced, barely missing statistical significance.

These real exchange rate movements, together with changes in relative demand, are largely matched by the bilateral trade balances. While the response of net imports of France is not distinguishable from zero, Spanish net imports from Germany increase significantly roughly six months after the shock and reach a peak of more than 50 million. To put this number into perspective, a cumulative increase in net exports of approximately 600 million over a horizon of one year (50 million per month) is equivalent to a 1.5 percent increase in the total yearly trade deficit of Spain of 43 billion. Net imports of Italy and Portugal also increase significantly in reaction to the shock. Finally, the impact responses of the trade balances are consistent with the idea that price effects dominate their dynamics in the very short run. While Spain experiences a real appreciation and a drop in nominal net imports, in France a real depreciation is matched with a jump in net imports. In sum, the results indicate that there is a heterogeneous reaction across countries to common monetary policy shocks that entails some adverse side effects on relative prices and internal trade balances.

\section{Conclusions}

In this paper, we estimate the macroeconomic effects of unconventional monetary policy in the euro area using structural VARs, identified with an external instrument. We find that monetary interventions are effective in stabilizing the real economy and in countering risks to financial and price stability. An expansionary shock leads to an increase in consumer prices, output, and inflation expectations.

The analysis contributes to the literature on the macroeconomic effectiveness of monetary policy. Our results are qualitatively similar to existing contributions, which find that unconventional monetary policy is effective and is transmitted to the real economy mainly through interest rates (see Wright, 2012, Baumeister and Benati, 2013, Kapetanios et al., 2012). Quantitatively, the dynamics of output and prices implied by our estimates are more similar to the response of these variables to conventional interest rate innovations (see Christiano et al., 1999, Gertler and 
Karadi, 2015) than to unconventional monetary policy shocks identified through changes in the central bank balance sheet (see Gambacorta et al., 2014, Boeckx et al., 2014, and Weale and Wieladek, 2016)

In addition, our estimates complement existing studies on unconventional monetary policy by revealing several fiscal and distributional side effects of this policy. First, we provide evidence that primary fiscal expenditures rise significantly following a monetary surprise expansion. Second, we document a heterogeneous reaction of fiscal policy across the currency union to the common monetary policy shock and show that output and prices also respond differently. This heterogeneity, in turn, is associated with a divergence of relative prices and a widening of existing trade imbalances within the union.

All in all, our findings could be interpreted as containing a note of caution to monetary policymakers: policies that, in principle, support the economy might lead to laxer fiscal policy and a widening of internal imbalances, thereby creating the potential for increased risks to future financial and economic stability. On the other hand, the pro-cyclical response of fiscal variables could also be viewed as enhancing the effectiveness of monetary policy as it crowds in fiscal policy. 


\section{References}

Altavilla, C., D. Giannone, and M. Lenza (2014). The financial and macroeconomic effects of OMT announcements. CEPR discussion paper no. 10025, CEPR.

Baumeister, C. and L. Benati (2013). Unconventional Monetary Policy and the Great Recession: Estimating the Macroeconomic Effects of a Spread Compression at the Zero Lower Bound. International Journal of Central Banking 9(2), $165-212$.

Blanchard, O. and F. Giavazzi (2002). Current Account Deficits in the Euro Area: The End of the Feldstein Horioka Puzzle? Brookings Papers on Economic Activity 33(2), 147-210.

Blinder, A. S., M. Ehrmann, M. Fratzscher, J. D. Haan, and D.-J. Jansen (2008, December). Central Bank Communication and Monetary Policy: A Survey of Theory and Evidence. Journal of Economic Literature 46(4), 910-45.

Boeckx, J., M. Dossche, and G. Peersman (2014). Effectiveness and Transmission of the ECB's Balance Sheet Policies. CESifo Working Paper Series 4907, CESifo Group Munich.

Cesa-Bianchi, A., G. Thwaites, and A. Vicondoa (2016, April). Monetary Policy Transmission in an Open Economy: New Data and Evidence from the United Kingdom. Discussion Papers 1612, Centre for Macroeconomics (CFM).

Chen, R., G. M. Milesi-Ferretti, and T. Tressel (2013). External imbalances in the eurozone. Economic Policy 28(73), 101-142.

Chow, G. C. and A. Lin (1971). Best linear unbiased interpolation, distribution, and extrapolation of time series by related series. The Review of Economics and Statistics 53(4), 372-75.

Christensen, J. H. and G. D. Rudebusch (2012). The response of interest rates to US and UK quantitative easing. The Economic Journal 122(564), F385-F414.

Christiano, L. J., M. Eichenbaum, and C. L. Evans (1999). Monetary policy shocks: What have we learned and to what end? Handbook of Macroeconomics 1, 65148.

Ciccarelli, M., A. Maddaloni, and J.-L. Peydró (2013). Heterogeneous transmission mechanism: monetary policy and financial fragility in the eurozone. Economic Policy 28(75), 459-512.

Commission, E. (2015, May). Assessment of the 2015 stability programme. Assessment of the 2015 stability programmes for various countries, Assessment of the 2015 Stability Programme. 
Comunale, M. and J. Hessel (2014). Current account imbalances in the Euro area: Competitiveness or financial cycle? DNB Working Papers 443, Netherlands Central Bank, Research Department.

Constancio, V. (2016, 13 April). International headwinds and the effectiveness of monetary policy. Speech at the 25th Annual Hyman P. Minsky Conference on the state of the US and World Economies at the Levy Economics Institute of Bard College, European Central Bank.

Darby, J. and J. Melitz (2008). Social spending and automatic stabilizers in the oecd. Economic Policy 23(56), 716-756.

Davig, T. and E. M. Leeper (2011). Monetary-fiscal policy interactions and fiscal stimulus. European Economic Review 55(2), 211-227.

den Haan, W. (2013). Forward guidance: perspectives from central bankers, scholars and market participants. Center for Economic Policy Research.

Draghi, M. (2015, 3 December). Introductory statement to the press conference (with q\&A). Q\&a, European Central Bank.

Draghi, M. (2016, 21 April). Introductory statement to the press conference (with q\&A). Q\&a, European Central Bank.

ECB (2015, Issue 6). ECB Economic Bulletin. Economic Bulletin, European Central Bank.

Ehrmann, M. and M. Fratzscher (2005). Equal size, equal role? interest rate interdependence between the euro area and the United States. The Economic Journal 115(506), 928-948.

Fragetta, M. and T. Kirsanova (2010). Strategic monetary and fiscal policy interactions: An empirical investigation. European Economic Review 54(7), 855-879.

Fratzscher, M., M. L. Duca, and R. Straub (2016). ECB unconventional monetary policy actions: Market impact, international spillovers and transmission channels. IMF Economic Review, forthcoming.

Gagnon, J., M. Raskin, J. Remache, and B. Sack (2011). The financial market effects of the federal reserve's large-scale asset purchases. International Journal of Central Banking 7(1), 3-43.

Gambacorta, L., B. Hofmann, and G. Peersman (2014). The effectiveness of unconventional monetary policy at the zero lower bound: A cross-country analysis. Journal of Money, Credit and Banking 46(4), 615-642.

Gertler, M. and P. Karadi (2015). Monetary policy surprises, credit costs, and economic activity. American Economic Journal: Macroeconomics 7(1), 44-76. 
Girouard, N. and C. André (2006). Measuring cyclically-adjusted budget balances for oecd countries. Available at SSRN 2005002.

Gürkaynak, R. S., B. P. Sack, and E. T. Swanson (2005). Do actions speak louder than words? The response of asset prices to monetary policy actions and statements. International Journal of Central Banking 1(1), 55-93.

Hamilton, J. D. and J. C. Wu (2012). The effectiveness of alternative monetary policy tools in a zero lower bound environment. Journal of Money, Credit and Banking 44 (s1), 3-46.

Kang, J. S. and J. C. Shambaugh (2016). The rise and fall of European current account deficits. Economic Policy 31(85), 153-199.

Kapetanios, G., H. Mumtaz, I. Stevens, and K. Theodoridis (2012). Assessing the economy-wide effects of quantitative easing. The Economic Journal 122(564), F316-F347.

Krishnamurthy, A. and A. Vissing-Jorgensen (2011). The effects of quantitative easing on interest rates: channels and implications for policy. Technical report, National Bureau of Economic Research.

Kuttner, K. N. (2001). Monetary policy surprises and interest rates: Evidence from the fed funds futures market. Journal of Monetary Economics 47(3), 523-544.

Leeper, E. M. (1991). Equilibria under activeand passive monetary and fiscal policies. Journal of Monetary Economics 27(1), 129-147.

Liikanen, E. (2015, 2 Febrary). Independence of monetary policy and the banking union. Speech at the Lamfalussy lecture conference (the Central Bank of Hungary), Budapest, Governor of the Bank of Finland.

Mertens, K. and M. O. Ravn (2013). The dynamic effects of personal and corporate income tax changes in the United States. The American Economic Review 103(4), 1212-1247.

Orphanides, A. (2016). Fiscal implications of central bank balance sheet policies. Discussion Paper 11383, Centre for Economic Policy Research.

Peersman, G. (2011, April). Macroeconomic Effects of Unconventional Monetary Policy in the Euro Area. CEPR Discussion Papers 8348, C.E.P.R. Discussion Papers.

Rogers, J. H., C. Scotti, and J. H. Wright (2014). Evaluating asset-market effects of unconventional monetary policy: a multi-country review. Economic Policy 29(80), 749-799.

Rogers, J. H., C. Scotti, and J. H. Wright (2016, May). Unconventional Monetary Policy and International Risk Premia. International Finance Discussion Papers 1172, Board of Governors of the Federal Reserve System (U.S.). 
Rossi, B. and S. Zubairy (2011). What is the importance of monetary and fiscal shocks in explaining US macroeconomic fluctuations? Journal of Money, Credit and Banking 43(6), 1247-1270.

Schmidt, C., P. Bofinger, I. Schnabel, L. Feld, and V. Wieland (2015). Annual economic report. Annual Economic Report 2015/16, German council of economic experts.

Stock, J. H. and M. W. Watson (2012). Disentangling the channels of the 2007-2009 recession. Brookings Papers on Economic Activity.

Traum, N. and S.-C. S. Yang (2011). Monetary and fiscal policy interactions in the post-war US. European Economic Review 55(1), 140-164.

Unger, R. (2015). Asymmetric credit growth and current account imbalances in the euro area. Discussion Papers 36/2015, Deutsche Bundesbank, Research Centre.

Van den Noord, P. (2000). The size and role of automatic fiscal stabilizers in the 1990s and beyond.

Weale, M. and T. Wieladek (2016). What are the macroeconomic effects of asset purchases? Journal of Monetary Economics 79(C), 81-93.

Weidmann, J. and K. Knot (2015, 23 march). Mario Draghi hits back at QE hawks. Article, Financial Times.

Wright, J. H. (2012). What does monetary policy do to long-term interest rates at the zero lower bound? The Economic Journal 122(564), F447-F466.

Wu, J. C. and F. D. Xia (2016). Measuring the macroeconomic impact of monetary policy at the zero lower bound. Journal of Money, Credit and Banking 48(2-3), 253-291.

Wyplosz, C. (2013, October). The Eurozone Crisis and the Competitiveness Legend. Asian Economic Papers 12(3), 63-81. 


\section{A Appendix: data and sources}

Table 3: Data construction and sources

\begin{tabular}{|c|c|}
\hline Variable & Construction and source \\
\hline Sovereign bond yields & Yield to redemption of sovereign bonds. Source: Datastream. \\
\hline $\begin{array}{l}\text { Euro area sovereign } \\
\text { bond yields without } \\
\text { Germany }\end{array}$ & $\begin{array}{l}\text { Synthetic yields for euro area bonds are computed as weighted averages of nine individual } \\
\text { countries: Austria, Belgium, Finland, France, Ireland, Italy, the Netherlands, Portugal, and } \\
\text { Spain. The weights are taken from euro area benchmark bond yields in Datastream. }\end{array}$ \\
\hline Stock market volatility & VStoxx option implied volatility. Source: Datastream. \\
\hline Credit measures & $\begin{array}{l}\text { Credit to non-financial firms, households, and monetary financial institutions. Source: ECB } \\
\text { data warehouse. Seasonally adjusted with X-ARIMA- } 13 \text {. }\end{array}$ \\
\hline Consumer price indices & Source: Datastream. \\
\hline $\begin{array}{l}\text { Real GDP and Indus- } \\
\text { trial Production }\end{array}$ & $\begin{array}{l}\text { Source: Datastream. Monthly IP series are seasonally adjusted with X-ARIMA-13. Quar- } \\
\text { terly GDP is interpolated using the series on IP and the method of Chow and Lin (1971). }\end{array}$ \\
\hline Unemployment Rates & Source: Eurostat. \\
\hline Inflation Expectations & $\begin{array}{l}\text { Source of survey data: Centre for European Economic Research (ZEW), Germany, and } \\
\text { European Commission. Source of inflation swaps: Datastream. }\end{array}$ \\
\hline Real activity indicators & Retail sales, new car registrations, and new orders in manufacturing. Source: Datastream. \\
\hline $\begin{array}{l}\text { Other financial market } \\
\text { variables }\end{array}$ & $\begin{array}{l}\text { Eurepo, Euribor, EUR/USD spot exchange rate, Euro Stoxx } 50 \text {, national stock price indices, } \\
\text { yields of corporate bond indices with } 2 \text { yr maturity and ratings AAA and BBB. Source: } \\
\text { Datastream. }\end{array}$ \\
\hline Oil Price & Price of Brent Crude Oil in US dollar. Source: Datastream. \\
\hline $\begin{array}{l}\text { Surprise component in } \\
\text { economic data releases }\end{array}$ & $\begin{array}{l}\text { Difference between the first-released data and the expected value (median expectation of a } \\
\text { panel of experts surveyed by Bloomberg). The difference is divided by the standard deviation } \\
\text { of the expectations. Source: Bloomberg. Variables from the following countries are included } \\
\text { (see Table } 4 \text { for details): Euro Area, Germany, France, Italy, Spain, the UK, and the US. }\end{array}$ \\
\hline Credit Rates & $\begin{array}{l}\text { Source: ECB / Datastream. Cons. Credit: Personal Lending Rates, New Loans, Consumer } \\
\text { Credit (Excluding Bank Overdrafts), 1-5 Years. House purchases: Personal Lending Rates, } \\
\text { New Loans, House Purchases (Excluding Bank Overdrafts), } 10 \text { Years +. Loans to NFC } \\
\text { (short): Prime Rates, New Loans, } 1 \text { Million Euro +, Excluding Bank Overdrafts, 1-5 Years. }\end{array}$ \\
\hline $\begin{array}{l}\text { Government budget } \\
\text { balance / debt }\end{array}$ & $\begin{array}{l}\text { Monthly euro area aggregated budget balance from Datastream. Seasonally adjusted with } \\
\text { X-ARIMA-12. Converted to real terms using euro area CPI. }\end{array}$ \\
\hline $\begin{array}{l}\text { Government debt-to- } \\
\text { GDP }\end{array}$ & $\begin{array}{l}\text { Quarterly debt-to-GDP for ten individual countries (Austria, Belgium, Finalnd, France, Ger- } \\
\text { many, Ireland, Italy, the Netherlands, Portugal, and Spain), aggregated using GDP weights. } \\
\text { Source: Datastream. Seasonally adjusted with X-ARIMA-12 and linearly interpolated to } \\
\text { monthly frequency. }\end{array}$ \\
\hline $\begin{array}{l}\text { Government revenues } \\
\text { and expenditures (to- } \\
\text { tal and in detail) }\end{array}$ & $\begin{array}{l}\text { Source: Eurostat (Consumption: intermediate consumption plus compensation of employees, } \\
\text { social security expenditure: social benefits and social transfers in kind, gross investment: cap- } \\
\text { ital expenditure). Euro area aggregates based on data for ten individual countries: Austria, } \\
\text { Belgium, Finalnd, France, Gremany, Ireland, Italy, the Netherlands, Portugal, and Spain. } \\
\text { Quarterly data is seasonally adjusted with X-ARIMA- } 12 / 13 \text { and then linearly interpolated } \\
\text { to the monthly frequency. Converted to real terms using CPIs. }\end{array}$ \\
\hline Net imports & $\begin{array}{l}\text { Imports minus exports vis-a-vis Germany. Source: German Federal Statistical Office } \\
\text { (Destatis). Seasonally adjusted with X-ARIMA- } 13 \text {. }\end{array}$ \\
\hline
\end{tabular}




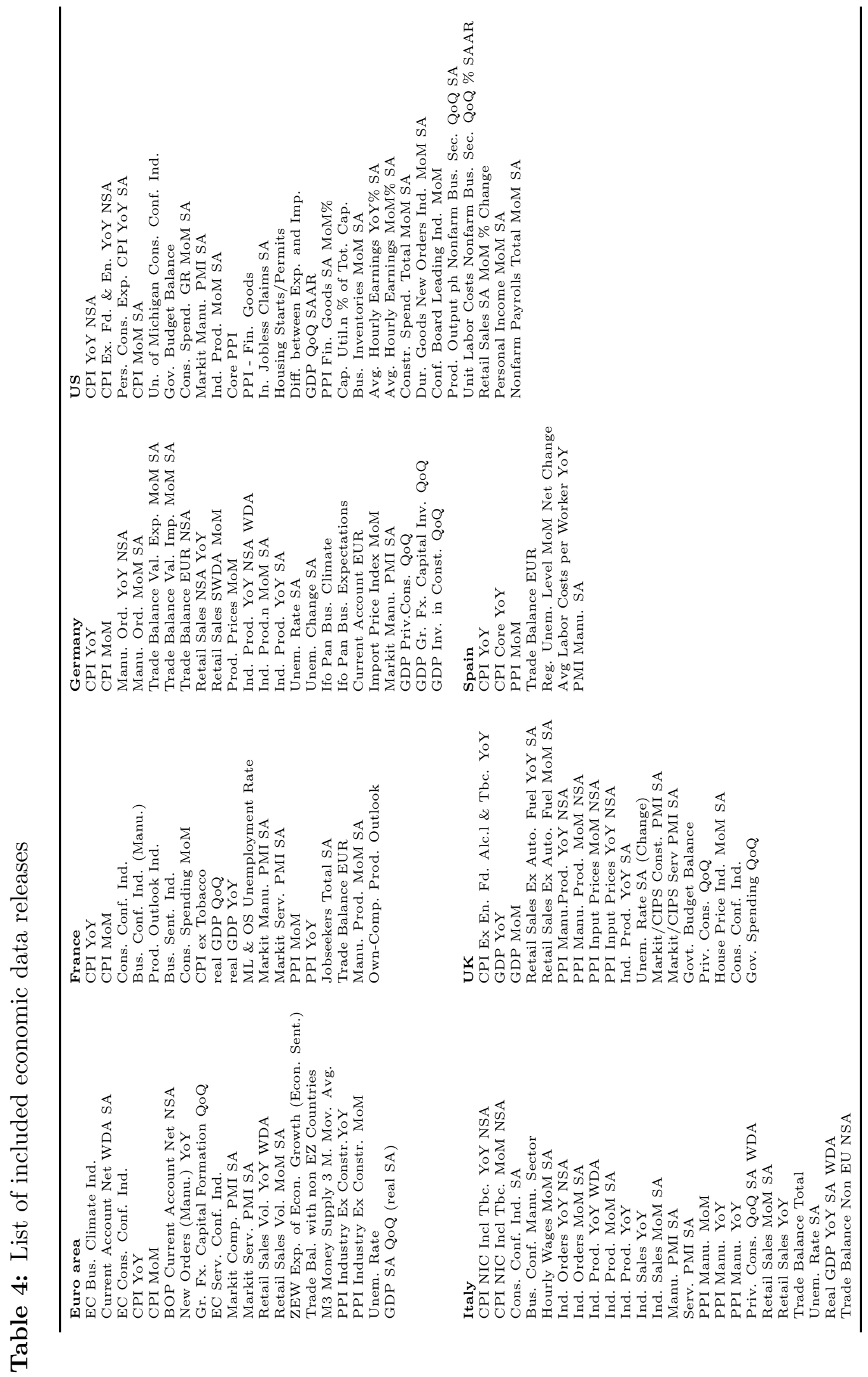


Table 5: List of included ECB Monetary Policy Announcements

\begin{tabular}{|c|c|}
\hline Date & Policy Announcement \\
\hline 22.08 .2007 & $\begin{array}{l}\text { Supplementary liquidity-providing longer-term refinancing } \\
\text { operation (LTRO) with a maturity of three months }\end{array}$ \\
\hline 28.03.2008 & LTROs with a maturity of six months \\
\hline 29.09 .2008 & Special term refinancing operation \\
\hline 08.10 .2008 & $\begin{array}{l}\text { Fixed rate tender procedure with full allotment } \\
\text { on the main refinancing operation(MROs) }\end{array}$ \\
\hline 15.10 .2008 & List of assets eligible as collateral in Eurosystem credit operations extended \\
\hline 07.05 .2009 & LTROs with a maturity of one year \\
\hline 04.06 .2009 & Details on Purchase program for covered bonds (CBPP) \\
\hline 03.12 .2009 & Phasing out of 6-month LTROs, indexation of new one year LTROs \\
\hline 04.03 .2010 & Phasing out of 3-month LTROs, indexation of six month LTROs \\
\hline 10.05 .2010 & Securities Markets Program (SMP) \\
\hline 28.07 .2010 & Risk control measures in collateral framework reviewed \\
\hline 03.03 .2011 & Further LTROs \\
\hline 09.06 .2011 & $\begin{array}{l}\text { MROs as fixed rate tender procedures with full allotment (FRFA) } \\
\text { for as long as necessary, at least until October } 2011\end{array}$ \\
\hline 04.08 .2011 & Further LTROs with a maturity of three and six months \\
\hline 08.08 .2011 & ECB will actively implement its Securities Market Program \\
\hline 06.10 .2011 & New covered bond purchase program (CBPP2) \\
\hline 08.12 .2011 & Two additional LTROs with a maturity of three years \\
\hline 21.12 .2011 & Results of first three year LTRO \\
\hline 09.02 .2012 & ECB's Governing Council approves eligibility criteria for additional credit claims \\
\hline 28.02 .2012 & Results of second three year LTRO \\
\hline 06.06 .2012 & FRFA on MROs as long as necessary, and at least until January 2013 \\
\hline 26.07 .2012 & 'Whatever it takes...' speech by ECB President Mario Draghi in London \\
\hline 02.08 .2012 & Outright Monetary Transactions program (OMT) \\
\hline 06.09 .2012 & Technical features of OMT \\
\hline 06.12 .2012 & FRFA on MROs as long as necessary, and at least until July 2013 \\
\hline 22.03 .2013 & Collateral rule changes for some uncovered government guaranteed bank bonds \\
\hline 02.05 .2013 & FRFA on MROs as long as necessary, and at least until July 2014 \\
\hline 04.07 .2013 & $\begin{array}{l}\text { Governing Council expects the key ECB interest rates to remain at present } \\
\text { or lower levels for an extended period of time (open-ended forward guidance) }\end{array}$ \\
\hline 08.11 .2013 & FRFA on MROs as long as necessary, and at least until July 2015 \\
\hline 05.06 .2014 & Targeted longer-term refinancing operations (TLTROs) \\
\hline 03.07.2014 & Details on TLTROs published \\
\hline 22.01 .2015 & Expanded asset purchase program \\
\hline
\end{tabular}




\section{B Appendix: additional figures}

Figure 7: Alternative measures of prices and inflation expectations.
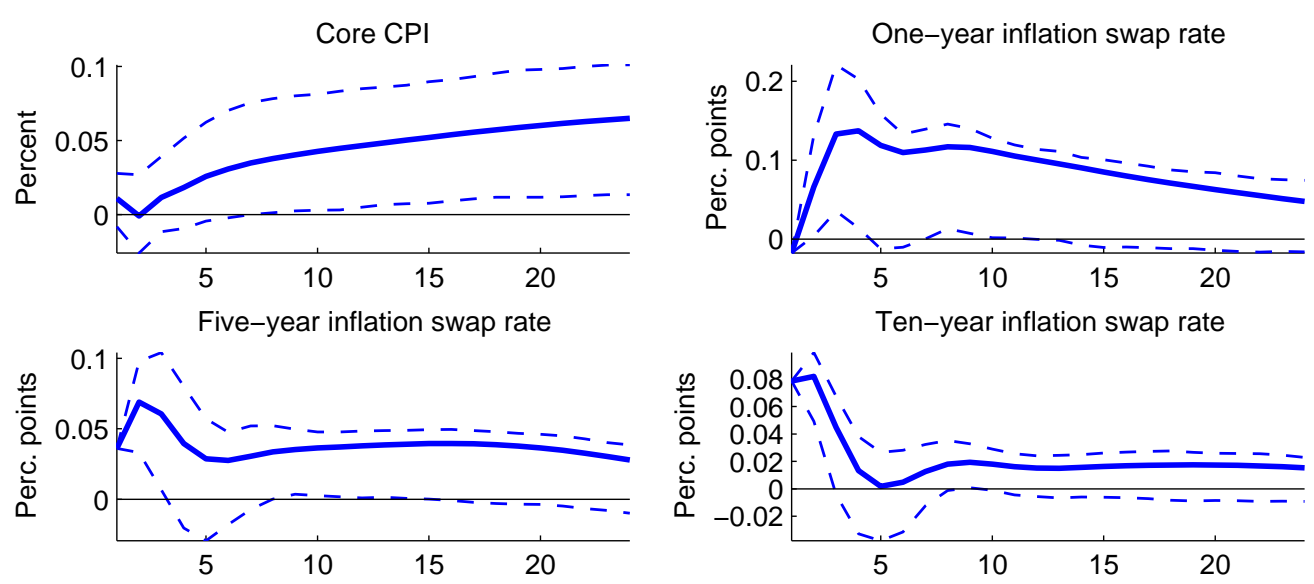

Note: The figure shows the estimated impulse responses, along with their 90 percent confidence bands obtained using 500 bootstrap replications, of selected euro area variables to a monetary policy shock that lowers the average two-year rate by 25 basis points. The sample is 1999M1 through 2015M6 for core inflation and 2008M9 through 2015M6 for the other variables.

Figure 8: Alternative measures of economic activity.
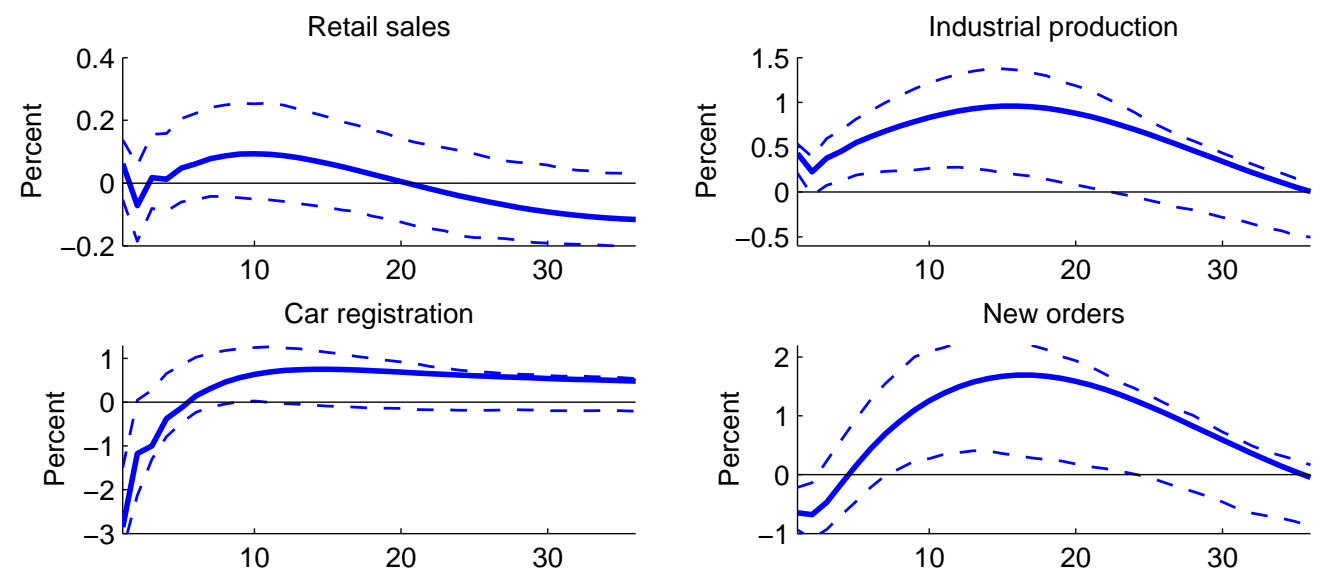

Note: The figure shows the estimated impulse responses, along with their 90 percent confidence bands obtained using 500 bootstrap replications, of selected euro area variables to a monetary policy shock that lowers the two-year rate on eurobonds by 25 basis points. The sample is 1999M1 through 2015M6. 
Figure 9: Other financial variables.
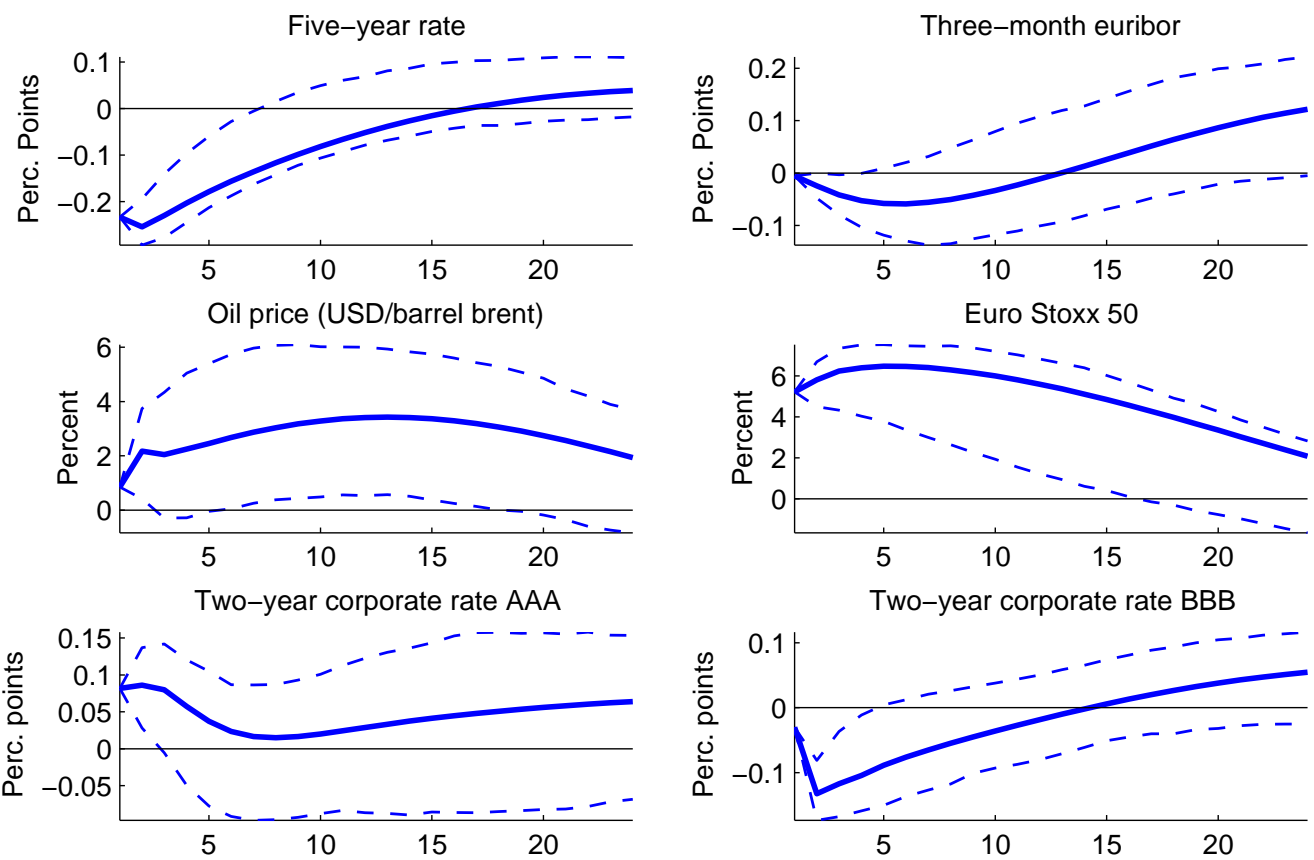

Note: The figure shows the estimated impulse responses, along with their 90 percent confidence bands obtained using 500 bootstrap replications, of selected euro area variables to a monetary policy shock that lowers the average two-year rate by 25 basis points. The sample is 1999M1 through 2015M6 for the first four variables and 2002M4 through 2015M6 for the corporate rates. 
Figure 10: Credit volume and credit rates.
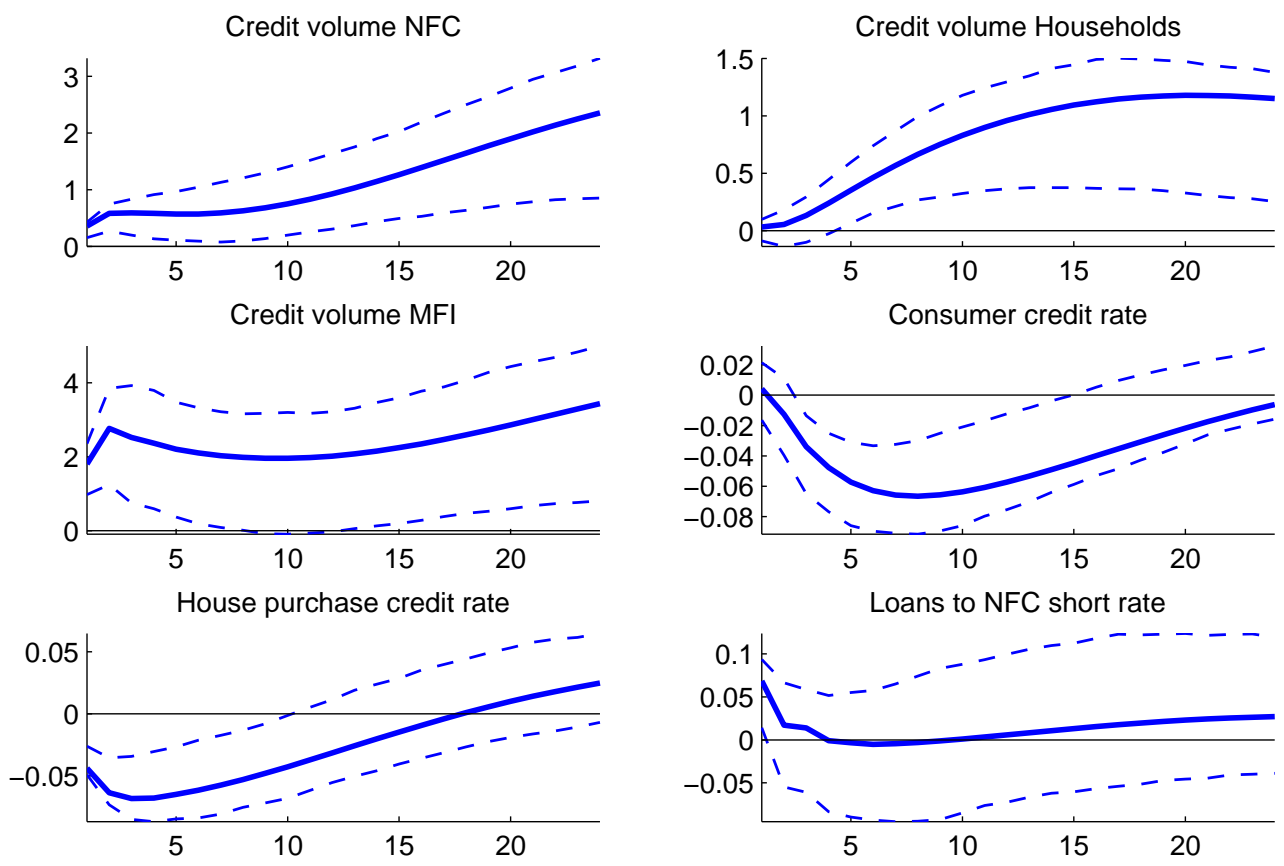

Note: The figure shows the estimated impulse responses, along with their 90 percent confidence bands obtained using 500 bootstrap replications, of selected euro area variables to a monetary policy shock that lowers the average two-year rate by 25 basis points. The sample is 2003M1 through 2015M6 for the house purchase rate, $2000 \mathrm{M} 1$ through 2015M6 for the other rates, and 1999M1 through 2015M6 for the credit volumes. 
Figure 11: Robustness of benchmark variables to including additional variables.
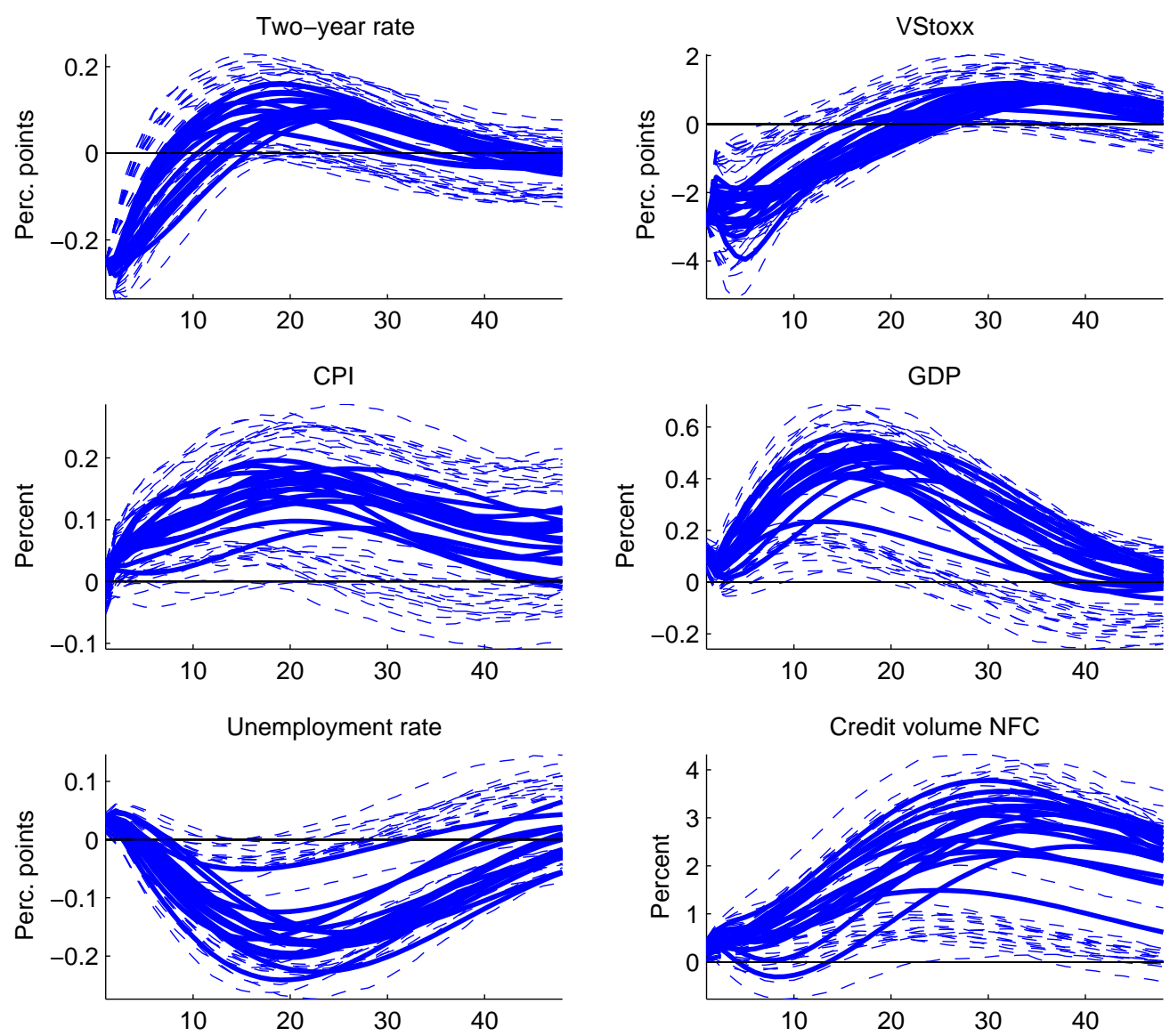

Note: The figure shows the estimated impulse responses, along with their 90 percent confidence bands obtained using 500 bootstrap replications, of the benchmark variables to a monetary policy shock that lowers the average two-year rate by 25 basis points when including additional variables, one at a time, to the benchmark VAR. Included are the variables from Figures 2 (expect for the swap rates), 3, 8, 9, and 10. The sample depends on the included marginal variable. 
Figure 12: Robustness of benchmark specification to not performing a Windsorization of the external instrument.
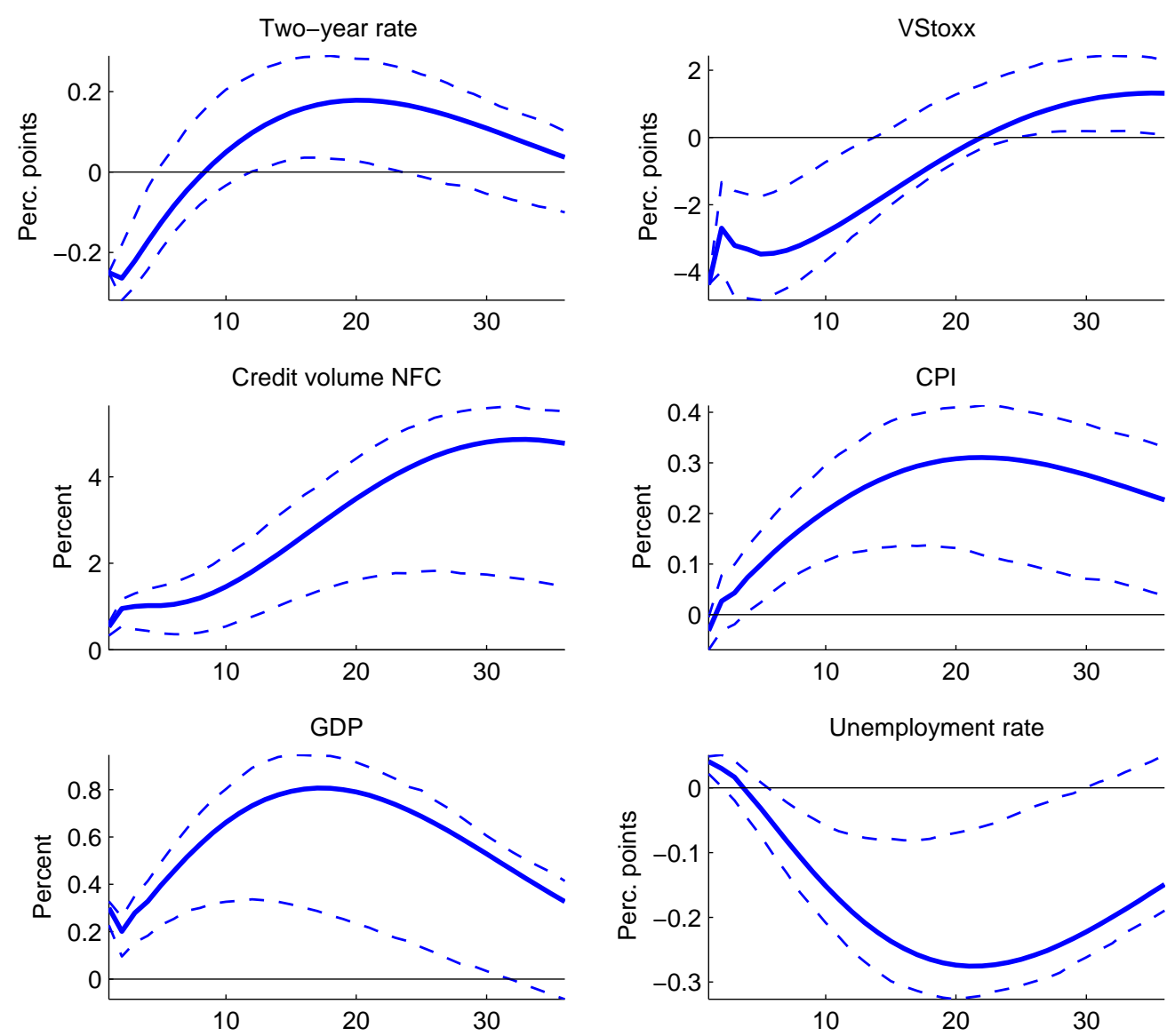

Note: The figure shows the estimated impulse responses, along with their 90 percent confidence bands obtained using 500 bootstrap replications, of selected euro area variables to a monetary policy shock that lowers the average two-year rate by 25 basis points. Different to the baseline specification, the instrument used to identify the monetary policy shock is not windsorized. The sample is 1999M1 through 2015M6. 
Figure 13: Robustness of benchmark specification to including German bond yields in the computation of the euro area average two-year rate.
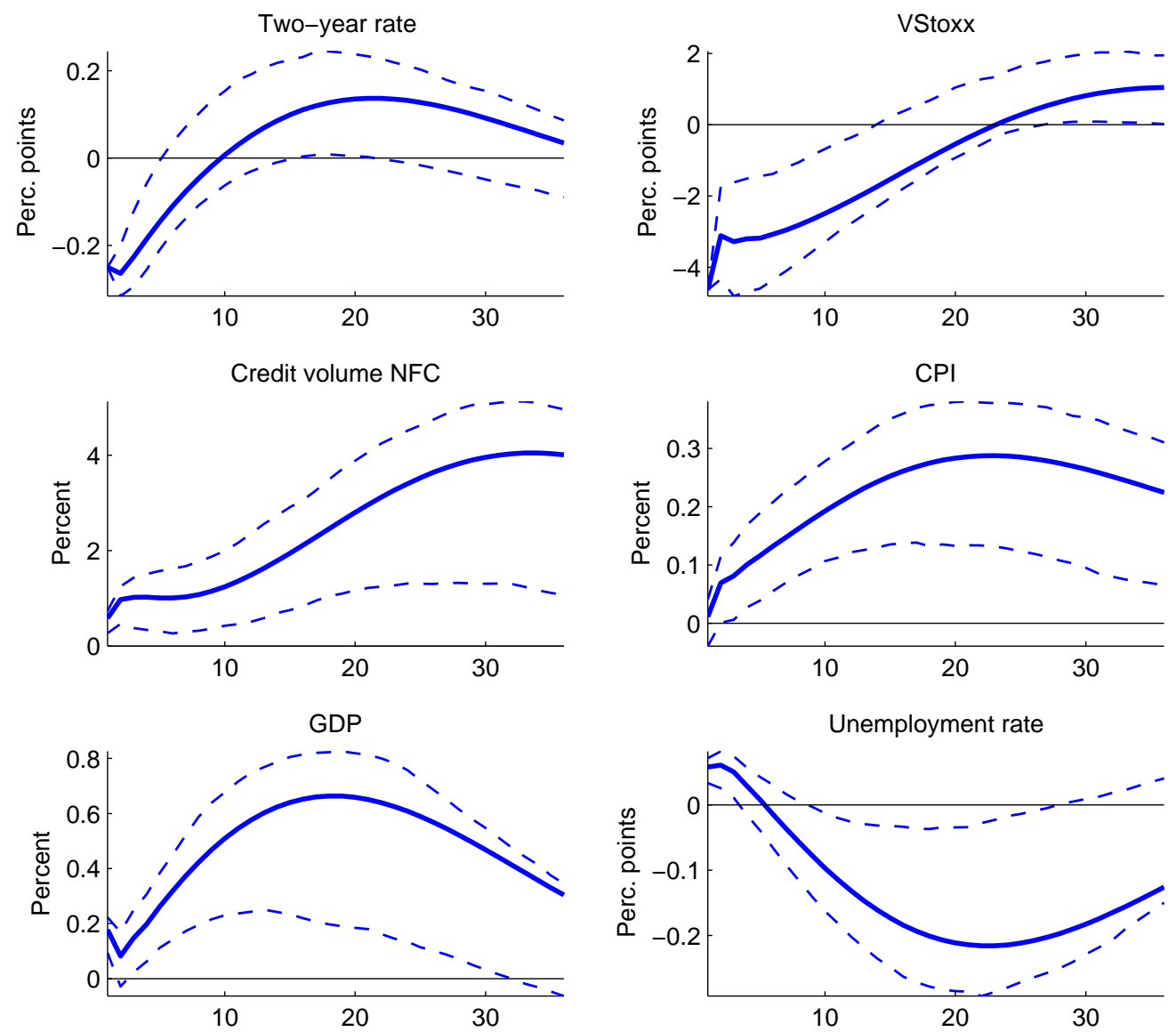

Note: The figure shows the estimated impulse responses, along with their 90 percent confidence bands obtained using 500 bootstrap replications, of selected euro area variables to a monetary policy shock that lowers the average two-year rate by 25 basis points. Different to the baseline specification, German yields are included in constructing the euro area bond rate. The sample is 1999M1 through 2015M6. 
Figure 14: Robustness of benchmark specification to using average euro area sovereign rates for different maturities as policy indicator.
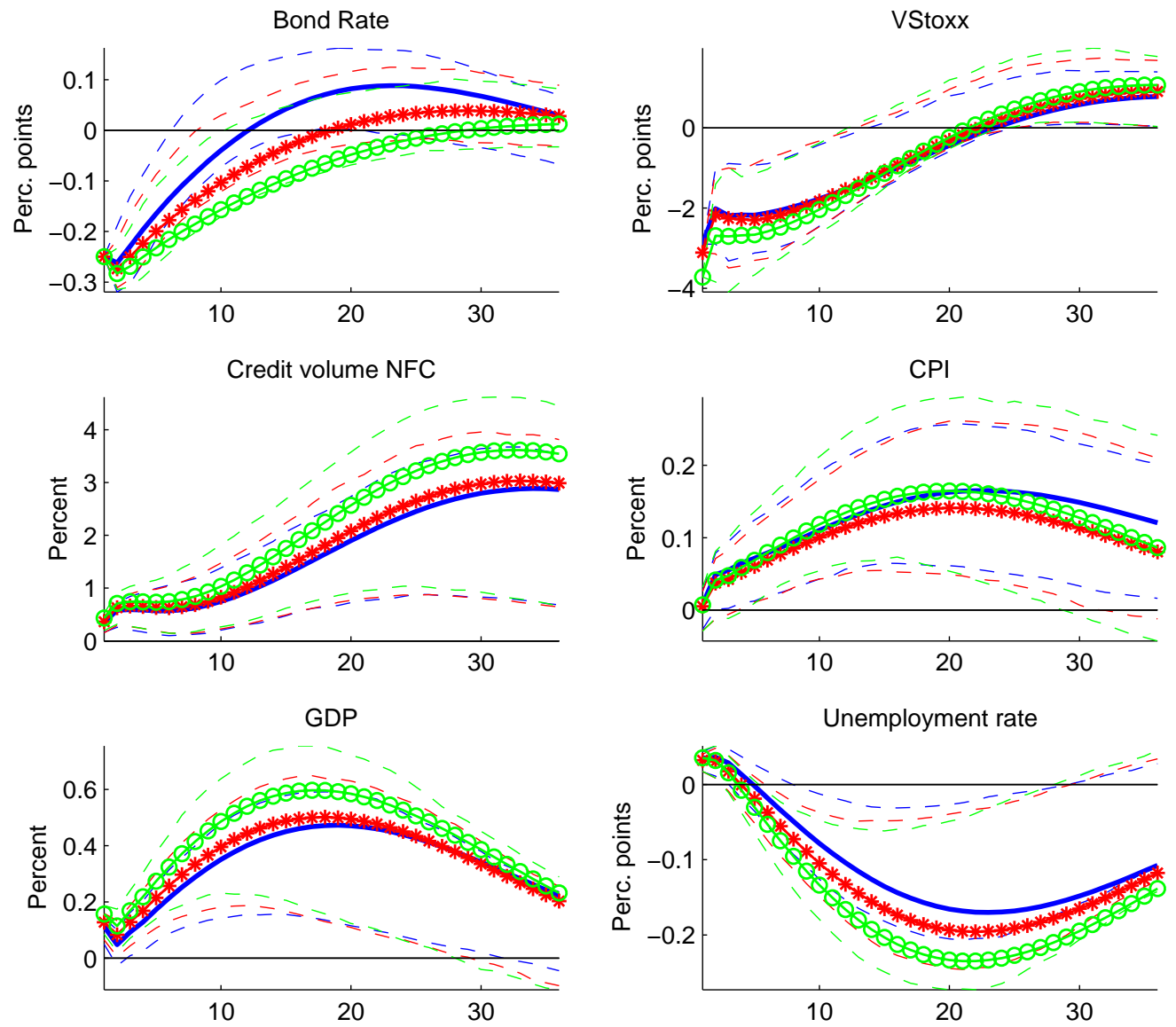

Note: The figure shows the estimated impulse responses, along with their 90 percent confidence bands obtained using 500 bootstrap replications, of selected euro area variables to a monetary policy shock that lowers either the average two-year rate (blue lines), the five-year rate (red lines, Asterisk) or the ten-year rate (green lines, Circles) by 25 basis points. The sample is 1999M1 through 2015M6. 
Figure 15: National government expenditures

Int. paym. FRA Gov. cons. FRA
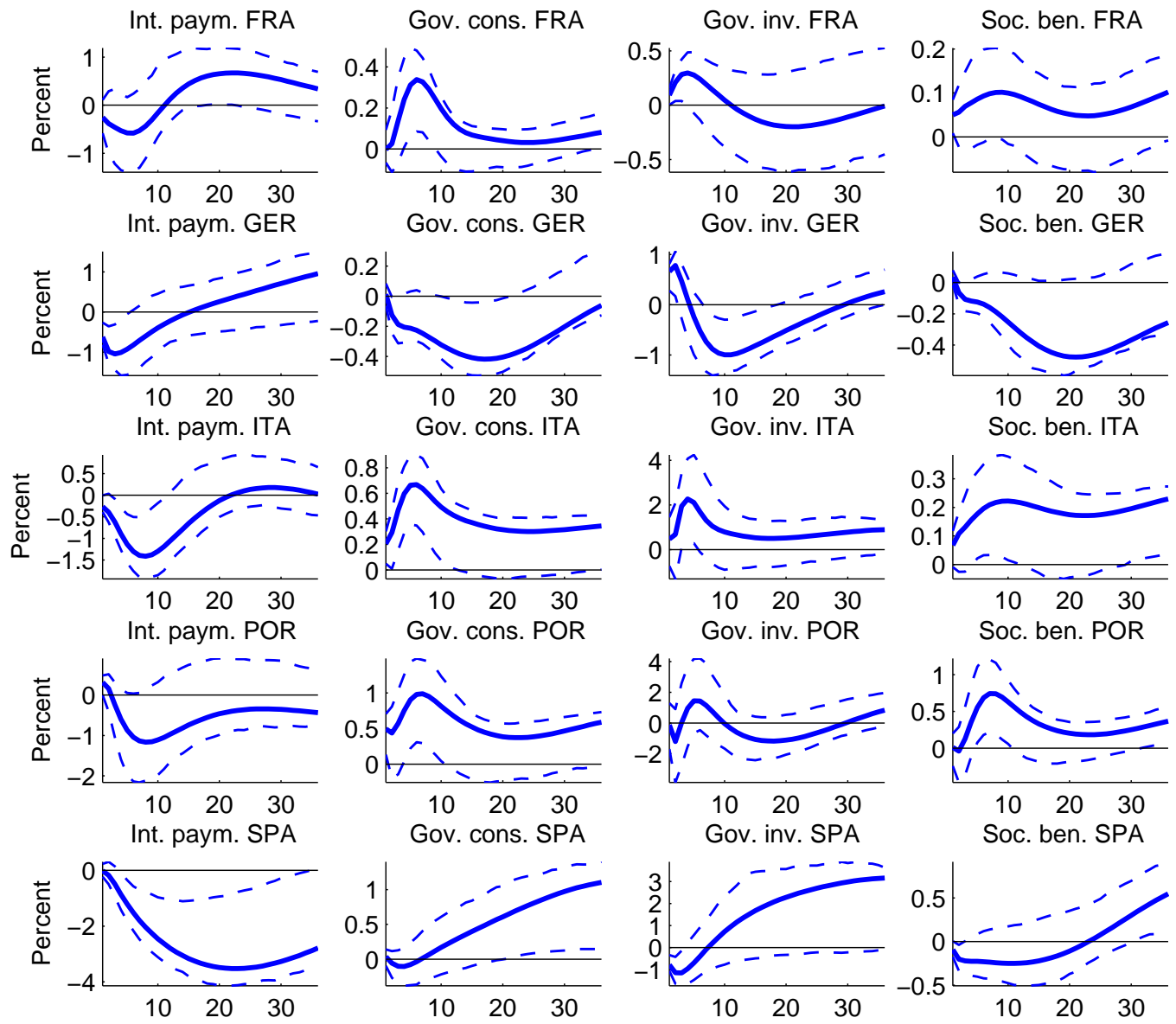

Note: The figure shows the estimated impulse responses, along with their 90 percent confidence bands, obtained using 500 bootstrap replications, of selected country-specific government expenditure components to a monetary policy shock that lowers the average two-year rate by 25 basis points. The sample is 2002M3 through 2015M6 for the German variables and 2000M3 through 2015M6 (interest payments) or 1999M1 through 2015M6 (consumption, investments, benefits) for the other countries. 
Figure 16: Baseline results for country level
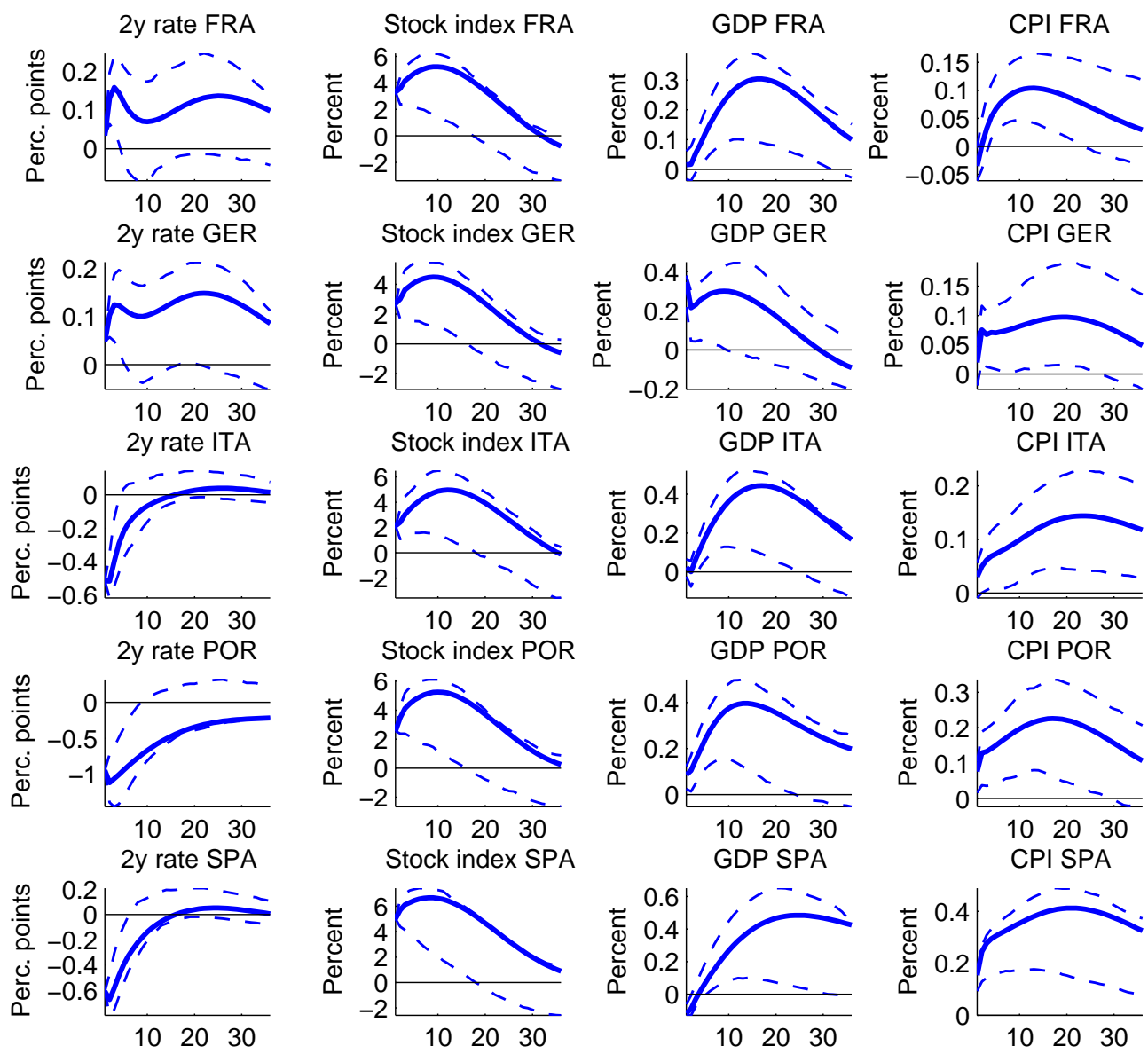

Note: The figure shows the estimated peak impulse responses of selected country-specific variables to a monetary policy shock that lowers the average two-year rate by 25 basis points. The sample is $2000 \mathrm{M} 1$ through $2015 \mathrm{M}$ for the stock indexes and 1999M1 through 2015M6 for the other variables. 